Review

\title{
Next-Generation Biomarkers in Multiple Myeloma: Understanding the Molecular Basis for Potential Use in Diagnosis and Prognosis
}

\author{
Amro M. Soliman ${ }^{1}\left(\mathbb{D}\right.$, Srijit Das ${ }^{2, *(\mathbb{D})}$ and Seong Lin Teoh ${ }^{3, *(\mathbb{D})}$ \\ 1 Department of Biological Sciences-Physiology, Cell and Developmental Biology, University of Alberta, \\ Edmonton, AB T6G 2R3, Canada; amsherif@ualberta.ca \\ 2 Department of Human \& Clinical Anatomy, College of Medicine \& Health Sciences, \\ Sultan Qaboos University, P.O. Box 35, Al-Khoud, Muscat 123, Oman \\ 3 Department of Anatomy, Faculty of Medicine, Universiti Kebangsaan Malaysia Medical Centre, \\ Kuala Lumpur 56000, Malaysia \\ * Correspondence: drsrijit@gmail.com (S.D.); teohseonglin@ppukm.ukm.edu.my (S.L.T.)
}

Citation: Soliman, A.M.; Das, S.; Teoh, S.L. Next-Generation Biomarkers in Multiple Myeloma: Understanding the Molecular Basis for Potential Use in Diagnosis and Prognosis. Int. J. Mol. Sci. 2021, 22, 7470. https://doi.org/10.3390/ ijms 22147470

Academic Editor: Franziska Jundt

Received: 5 June 2021

Accepted: 2 July 2021

Published: 13 July 2021

Publisher's Note: MDPI stays neutral with regard to jurisdictional claims in published maps and institutional affiliations.

Copyright: (c) 2021 by the authors. Licensee MDPI, Basel, Switzerland. This article is an open access article distributed under the terms and conditions of the Creative Commons Attribution (CC BY) license (https:/ / creativecommons.org/licenses/by/ $4.0 /)$.

\begin{abstract}
Multiple myeloma (MM) is considered to be the second most common blood malignancy and it is characterized by abnormal proliferation and an accumulation of malignant plasma cells in the bone marrow. Although the currently utilized markers in the diagnosis and assessment of MM are showing promising results, the incidence and mortality rate of the disease are still high. Therefore, exploring and developing better diagnostic or prognostic biomarkers have drawn global interest. In the present review, we highlight some of the recently reported and investigated novel biomarkers that have great potentials as diagnostic and/or prognostic tools in MM. These biomarkers include angiogenic markers, miRNAs as well as proteomic and immunological biomarkers. Moreover, we present some of the advanced methodologies that could be utilized in the early and competent diagnosis of MM. The present review also focuses on understanding the molecular concepts and pathways involved in these biomarkers in order to validate and efficiently utilize them. The present review may also help in identifying areas of improvement for better diagnosis and superior outcomes of MM.
\end{abstract}

Keywords: multiple myeloma; diagnostic markers; prognostic markers; miRNAs; angiogenic markers; liquid biopsy; telomeres; proteomics

\section{Introduction}

Multiple myeloma (MM), also known as plasma cell myeloma, is a clonal plasma cell (PC) malignancy. Subsequent to PCs' maturation in lymph nodes, they migrate to the bone marrow (BM), where they undergo malignant changes to develop the disease [1,2]. The abnormal proliferation of PCs leads to the extensive involvement of the skeletal system, with osteopenia/osteolytic lesions, anemia, hypercalcemia and soft tissue plasmacytomas [3,4].

Being the second most common blood cancer, MM accounts for $13 \%$ of all hematologic malignancies worldwide [5-7]. In the United States of America, more than 230,000 cases of MM were reported between 2011 and 2016 [5,8]. The overall survival (OS) of MM patients was 30 months and could be extended to 46 months with Thalidomide treatment, and 48 months by BM transplantation [9]. More importantly, the survival rate is lower in patients with a higher ISS stage, suggesting that an early and competent diagnosis of MM may promote the survival rate [10].

MM patients are usually preceded by pre-malignant asymptomatic stages, recognized as the monoclonal gammopathy of undetermined significance (MGUS) or smoldering MM (SMM) that progresses towards symptomatic medullary and extramedullary MM [11]. Although there are several established biomarkers that are currently utilized for diagnosis of MM, assessment of tumor burden and risk-stratifying patients [2], the incidence of MM 
cases is progressively increasing. Therefore, researchers are investigating the development of novel biomarkers that could help in better diagnosis, prognosis, or treatment. Characterizing effective, sensitive and specific diagnostic and/or prognostic biomarkers is essential to detect the disease at early stages, thus effectively combating the malignancy. Numerous studies are currently investigating several novel biomarkers that can be used in the diagnosis and prognosis of myeloma disease. Fortunately, advances in understanding the biology of the disease opened the door to the development of new diagnostic and prognostic approaches. A thorough comprehension of the pathogenesis of $\mathrm{MM}$ and the molecular concepts of these novel biomarkers are vital for their validation and proper utilization.

In the present review, we comprehensively explain the recently reported biomarkers that can be utilized for the diagnosis, prognosis and management of $\mathrm{MM}$, along with their underlying molecular mechanisms. Furthermore, we highlight the limitations and future areas of improvements of these biomarkers.

\section{Molecular Pathogenesis and Current Biomarkers of MM}

Although the exact cause of MM is still undetermined, several genetic mutations are related to $\mathrm{MM}$ development. The intraclonal genetic heterogeneity of PCs drives the progression of the disease [12]. Particular cytogenetic variations correlated with the development of MGUS, while other oncogenes and mutations were linked to the progression of MGUS to MM or extramedullary MM (Figure 1) [13,14]. Furthermore, cytogenetic alternations were found to greatly impact the treatment outcome, drug resistance and prognosis of MM [14].

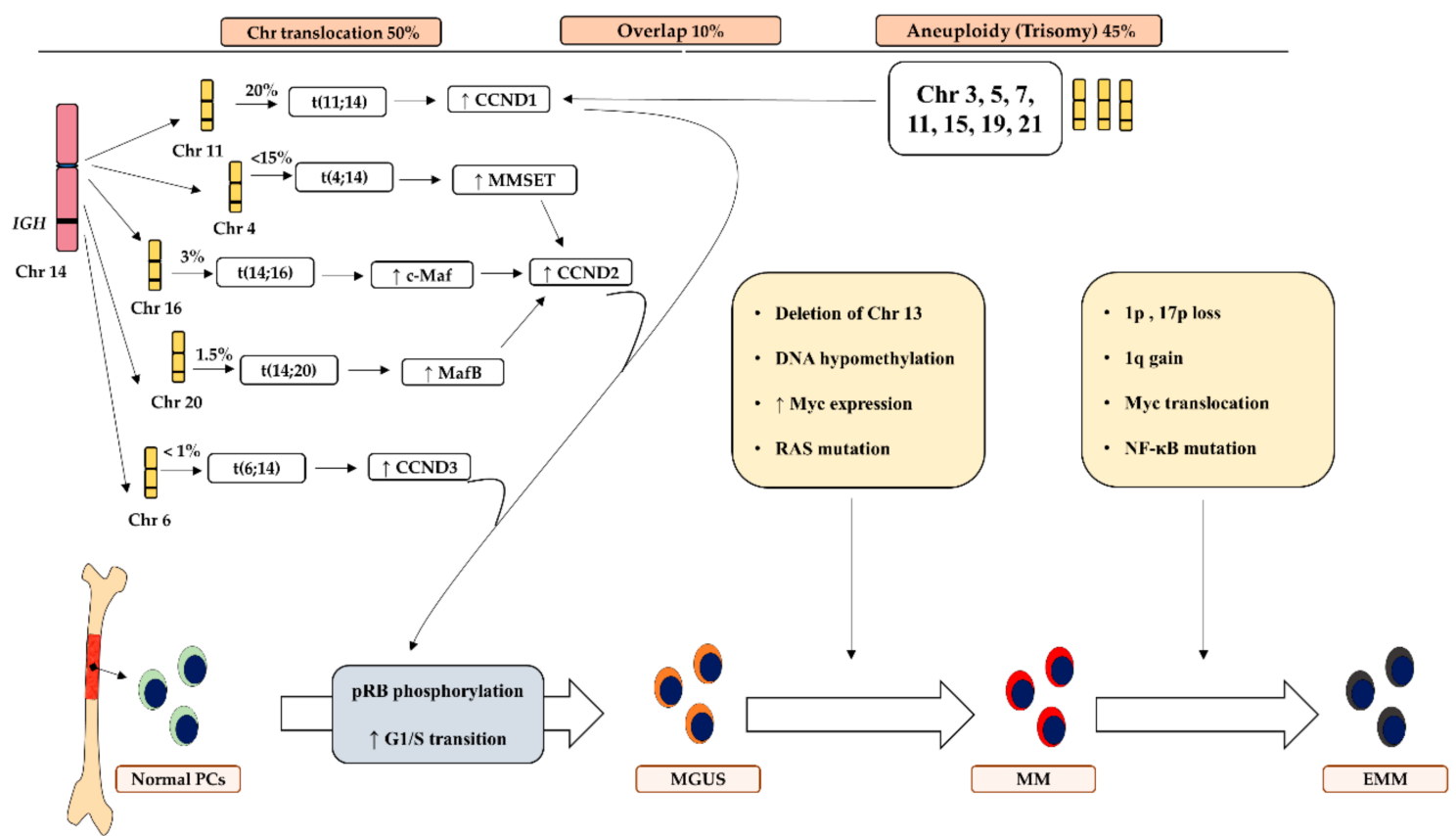

Figure 1. Molecular pathogenesis and underlying cytogenic alterations associated with MM development. Chromosomal translocations and aneuploidy disrupt cyclin D genes that in turn enhance G1/S transition of the cell cycle to induce abnormal cellular proliferation in plasma cells to develop MGUS. Other genetic mutations were found to be associated with the transformation of the disease towards MM and EMM. IGH; Immunoglobulin H, Chr: chromosome, PCs: plasma cells; MGUS: monoclonal gammopathy of undetermined significance, SMM: smoldering multiple myeloma, EMM: extramedullary multiple myeloma, CCDN: cyclin D, MMSET: multiple myeloma SET domain, NF-kB: nuclear factor kappa-light-chainenhancer of activated B cells, BM: bone marrow.

Normally, PCs remain in an arrested state by holding their cell cycle at G0/G1 phase in the BM unless activated by a microbial challenge. To develop MM, these cells acquire abnormal growth and proliferation capabilities. This is where the genetic alterations play 
a role by dysregulating critical pathways involved in controlling G0/G1 transition [15]. Chromosomal translocation, aneuploidy and chromosomal deletion contribute significantly to MM development via targeting the cyclin D (CCDN) family, a crucial regulator of G0/G1, through several pathways (Figure 1). The most common translocation in MM is $\mathrm{t}(11 ; 14)(\mathrm{q} 13 ; \mathrm{q} 32)$, which was detected in $20 \%$ of MM patients and involved the translocation of the immunoglobulin heavy chain $(\mathrm{IgH})$ gene locus [16]. The $t(11 ; 14)$ is also associated with a poorer outcome in MM patients [16]. Additionally, translocation of the immunoglobulin lambda ( $\operatorname{IgL}$ ) gene locus was also reported in $10 \%$ of MM patients, and also served as an indicator of poor prognosis [17].

The evolvement of MGUS to MM was shown to be associated with the up-regulation of oncogenes such as Myc and Ras [18,19], chromosome deletion and other factors [20]. The activation of Myc was suggested to be induced by super enhancer-mediated hyperactivation of transcription that could be experimentally blocked via small molecular inhibitors, thus representing a potential drug target [21,22]. Other contributors encompass DNA hypomethylation, which causes genome instability $[20,23]$.

Developing and establishing diagnostic tools is increasingly becoming critical for managing MM. Currently, several biomarkers are deployed for diagnosis and prognosis of the disease (Figure 2). The levels of these biomarkers are evaluated based on diagnostic procedures such as BM biopsy, serum analysis, 24-hour urine analysis, metaphase karyotyping, Fluorescence In Situ Hybridization (FISH) and imaging [24]. The assessment of monoclonal protein (M protein), the abnormal immunoglobulin (Ig) produced by malignant PCs and the free light chain (FLC) level in the serum and urine of MM patients is critical for diagnosis. Similarly, detecting chromosomal abnormalities and osteolytic bone lesions help in risk-stratifying of MM cases.
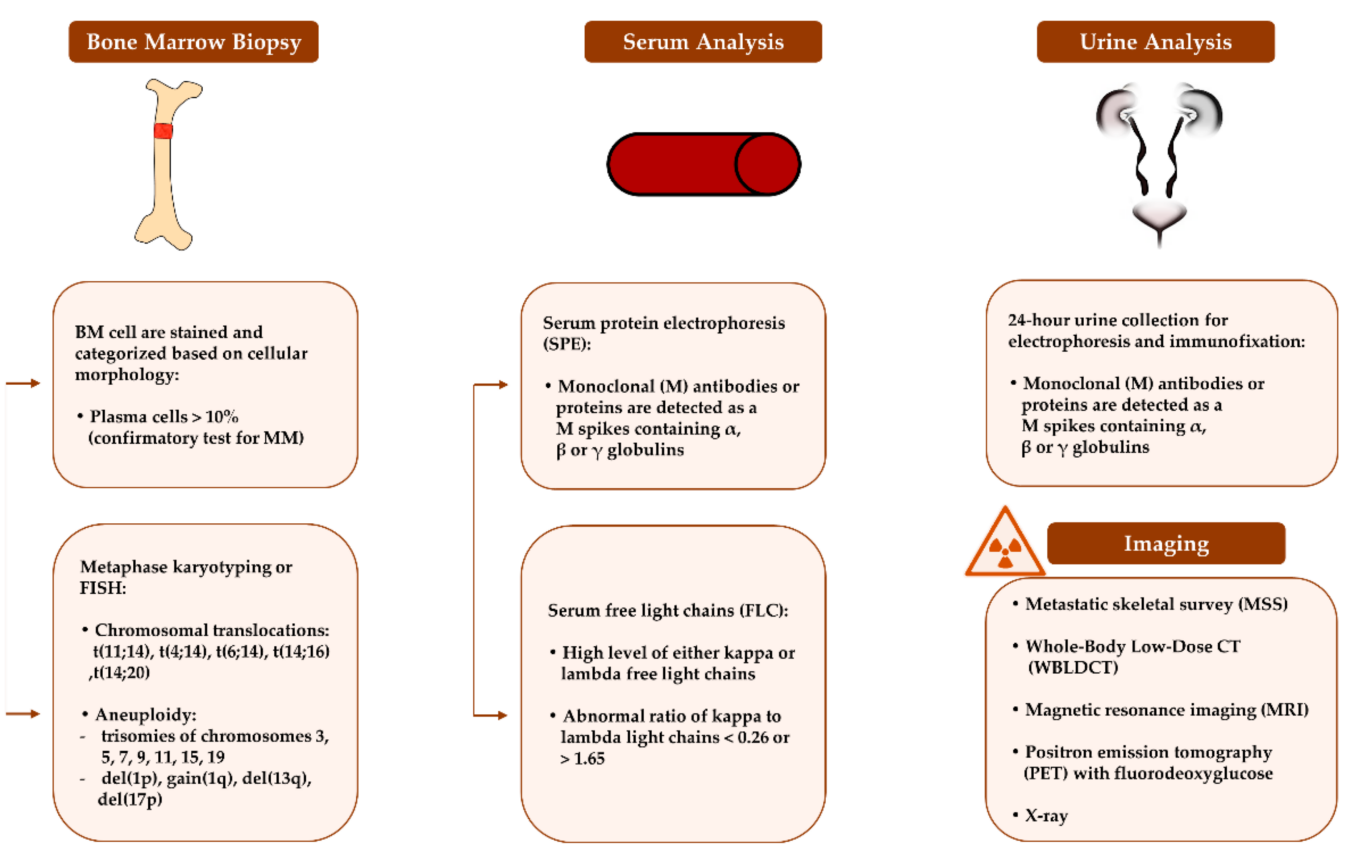

Figure 2. Biomarkers that are currently utilized for diagnosis and risk-stratifying of multiple myeloma.

Guidelines were developed for differentiating the phases of MM concerning early asymptomatic phases of the disease, e.g., MGUS, in addition to the more advanced, symptomatic phases that comprise medullary and extramedullary MM. The International Myeloma Working Group (IMWG) presented diagnostic benchmarks for MM and its differential phases, including IgM MGUS, Non-IgM MGUS, Light chain MGUS and SMM [25]. These diagnostic criteria considered several biomarkers that involved the serum or urinary levels of the $\mathrm{M}$ protein and evidence of end-organ failure that was judged by serum levels of calcium, hemoglobin $(\mathrm{Hb})$ and creatinine [25]. Other established guidelines for MM stag- 
ing incorporated two systems, i.e., the Durie-Salmon PLUS System (DSS) and the revised International Staging System (ISS) (Figure 3). Both the DSS and the ISS are primarily used for classifying the progression and advancement of the MM to determine the most suitable and effective treatment protocols as well as to assess the median survival. These staging systems also depend mainly on the serum or urine levels of specific biomarkers in addition to allied cytogenic alterations $[26,27]$.

\section{Staging}
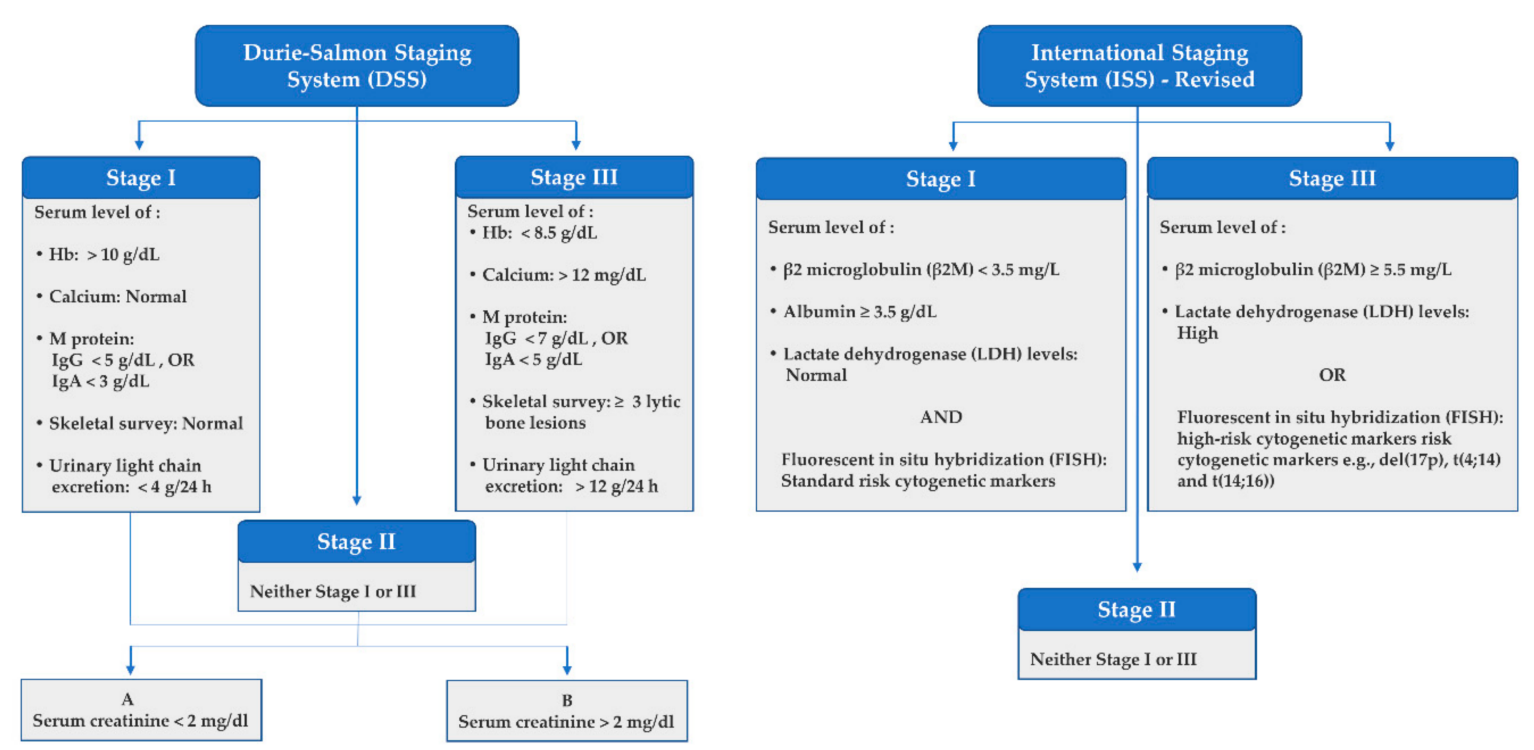

Figure 3. Multiple myeloma staging systems: Durie-Salmon PLUS System (DSS) and revised International Staging System (ISS).

Both IMWG criteria and staging systems are crucial for the management of MM; however, they are reliant on diagnostic and prognostic biomarkers such as $\mathrm{M}$ protein and $\beta 2$-microglobulin levels. Therefore, the stability and reproducibility of these diagnostic and staging guidelines are liable to the sensitivity and consistency of these biomarkers. M-protein, for example, is not detected in about 18\% of MM cases via serum protein electrophoresis [28], with nearly $3 \%$ of MM patients having no reportable trace of $\mathrm{M}$ protein [29], resulting in misdiagnosis and inaccurate staging in those cases. Furthermore, $\beta 2$-microglobulin levels could be affected by several factors, including kidney and liver diseases. As a result, several research groups are currently investigating the utilization of other novel biomarkers that can overcome the limitations associated with current diagnostic tools.

\section{Novel Biomarkers for Diagnosis and Prognosis of MM}

Due to the progressively increasing numbers of MM cases, despite the currently used diagnostic and prognostic biomarkers, several next-generation biomarkers are currently emerging that could enhance clinical management and improve the outcome of the disease. In the following sections, we report the recently reported biomarkers with their underlying molecular mechanisms. Moreover, we illustrate their potential and areas of improvement to establish these biomarkers in future guidelines for early diagnosis and accurate assessment of the disease.

\subsection{Angiogenesis Markers}

To maintain their expediated growth and cellular proliferation, malignancies promote new blood vessel formation, a process known as angiogenesis, to sufficiently supply cancer 
cells with oxygen and nutrients, and for waste disposal [30]. In cancer, this may involve the increased production of activators (pro-angiogenic factors) or loss of inhibitors (antiangiogenic factors). Therefore, angiogenic markers are considered crucial tumor markers in various malignancies. Several pro-angiogenic factors were characterized in the past few decades. Hepatocyte growth factor (HGF), vascular endothelial growth factor (VEGF), fibroblast growth factor (FGF) and angiopoietins represent key pro-angiogenic signals. Among these signals, VEGF was reported to be over-expressed in several malignancies and it has been well studied as a potential therapeutic target [31-33]. In MM, VEGF, in addition to HGF, angiopoietins and JunB were up-regulated, where they demonstrated a potential diagnostic and prognostic marker [34-36]. The experimental down-regulation of VEGF by chemotherapeutic agents and herbal products was associated with a significant reduction in cellular proliferation and an increase in apoptotic myeloma cells [37-39]. Similarly, other pro-angiogenic factors such as angiopoietin-1, angiopoietin-2 and HGF expression were impeded by these therapeutic applications, suggesting their potential as prognostic biomarkers [38].

The molecular pathways regulating angiogenesis in MM include epidermal growth factor receptor (EGFR) and its ligand heparin-binding EGF-like growth factor (HB-EGF). The HB-EGF-EGFR pathway was found to promote endothelial cell proliferation in BM angiogenesis in vivo and in vitro [40]. Moreover, the high expression levels of EGFR and HB-EGF in MM cells, when compared with cells from MGUS patients, were associated with an increase in the percentage of MM PCs. Furthermore, inhibiting the HB-EGF-EGFR signaling pathway resulted in limiting the angiogenic ability of BM endothelial cells [40]. Other angiogenic pathways involve BM thrombopoietin (TPO), which was revealed to maintain and endorse angiogenesis in MM. Interestingly, the TPO level varies significantly at different phases of MM. For instance, BM and serum TPO increased remarkably with the progression from MGUS/SMM to MM, suggesting its utilization as a potential biomarker in MM diagnosis and prognosis [41]. TPO receptors are expressed in BM endothelial cells, where they are activated to trigger intracellular angiogenic signaling pathways that enhance cell migration and chemotaxis in vitro as well as up-regulating matrix metalloproteinase (MMP)-9 and MMP-2, disrupting the balance between the angiogenic/anti-angiogenic factors in the BM [41].

Mesenchymal stromal cells are non-hematopoietic multipotent cells that play an important role in MM development and progression via coordinating cellular migration and enhancing angiogenesis [42]. The stromal cells cultured with MM cell lines (U266/Lp-1) under hypoxic conditions were associated with a rise in $\alpha$-smooth muscle actin, hypoxiainducible factor (HIF)-2 $\alpha$ and integrin-linked kinase proteins, indicating their role as potential angiogenic markers [43]. Interestingly, the inhibition of HIF- $2 \alpha$ reduced both $\alpha$-smooth muscle actin and integrin-linked kinase, resulting in attenuating angiogenesis in vitro. Mechanistically, the HIF- $2 \alpha$ released by stromal cells promotes angiogenesis via increasing the attachment of Q-dot labeled cells and the excretion of angiogenic factors [43]. Along with the role of these angiogenic markers in the diagnosis/prognosis of MM, they represent possible drug targets.

The implications of using angiogenic markers have been progressively increasing. A recent clinical trial by Hofmann et al. [44] investigated the serum level of pro-angiogenic markers in patients diagnosed with MM and non-progressing MGUS. The study identified the following three angiogenesis markers that were correlated with future progression from MGUS to MM: EGF, HGF and angiopoietins-2. These composite angiogenic biomarkers are a potential stratified risk of MGUS progression to MM, which can be added to the established guidelines to improve risk stratification models for MGUS patients. Additionally, high FGF-2 and VEGF plasma levels were negative prognostic markers and were associated with a lower OS in MM patients receiving treatment [45]. More clinical studies encompassing a larger sample size and more angiogenesis-related signals are encouraged to enhance the sensitivity and specificity of these markers. 


\section{2. microRNAs}

MicroRNAs (miRNAs) are small non-coding RNAs composed of 18-25 nucleotides that regulate the gene expression via targeting the mRNA affecting various biological processes such as cell proliferation, migration and apoptosis. For decades, researchers have characterized the involvement of miRNAs in the development and progression of various malignancies [46-49]. They may act as tumor oncogenes or tumor suppressor genes to either enhance or impede tumor growth, respectively. We have previously elaborated the potential role of miRNAs in the diagnosis and prognosis of MM [50]. MiRNAs can potentially serve as molecular biomarkers for MM due to the variable miRNAs detected at different stages of the diseases, therefore providing insights into the diagnosis/prognosis of MM patients [51-55]. Furthermore, miRNAs can be detected in a variety of body fluids, such as plasma, serum and urine, along with being stable for several hours, even at room temperature, thus employing the feasibility and advantage of utilizing non-invasive procedures for miRNAs' characterization [56,57]. Table 1 summarizes a few miRNAs that can be utilized as diagnostic/prognostic biomarkers in MM.

Table 1. MiRNAs acting as potential diagnostic and/or prognostic biomarkers in MM and their molecular targets.

\begin{tabular}{|c|c|c|c|}
\hline miRNA & Expression & Potential Molecular Pathways & Ref. \\
\hline $\begin{array}{l}\operatorname{miR}-15 a \text { and } \\
\text { miR-16a }\end{array}$ & $\downarrow$ & $\begin{array}{l}\text { Regulate proliferation and growth of MM cells in vitro and in vivo via } \\
\text { inhibiting AKT serine/threonine-protein-kinase (AKT3), ribosomal-protein-S6, } \\
\text { MAP-kinases and NF-kB-activator MAP3KIP3 }\end{array}$ & [58] \\
\hline miR-16 & $\downarrow$ & $\begin{array}{l}\text { BMSCs-induced overproduction of IL- } 6 \text { reduces miR- } 16 \text { expression, thus } \\
\text { enhancing cellular proliferation and drug resistance }\end{array}$ & {$[59,60]$} \\
\hline $\operatorname{miR}-17$ & $\uparrow$ & $\begin{array}{l}\text { Targets PTEN, E2F1 and Bcl2111/BIM pathways, thereby enhancing tumor } \\
\text { growth }\end{array}$ & {$[61,62]$} \\
\hline $\operatorname{miR}-19 b$ & $\downarrow$ & $\begin{array}{l}\text { Controls proliferation of cancer stem cells by regulating the TSC } 1 / \mathrm{mTOR} \\
\text { signaling pathway }\end{array}$ & {$[63,64]$} \\
\hline $\operatorname{miR}-25$ & $\downarrow$ & Regulates TNF-related apoptosis-inducing ligand (TRAIL)-induced cell death & {$[64,65]$} \\
\hline $\operatorname{miR}-92$ & $\uparrow$ & $\begin{array}{l}\text { Targets PTEN, E2F1 and Bcl2111/BIM pathways, thereby enhancing tumor } \\
\text { growth }\end{array}$ & {$[61,62]$} \\
\hline $\operatorname{miR}-92 a$ & $\uparrow$ & Induces time-dependent down-regulation of c-jun & {$[64,66]$} \\
\hline miR-125b-5p & $\uparrow$ & Inhibited PHLPP2, leading to elevated Akt signaling & {$[67,68]$} \\
\hline $\operatorname{miR}-129$ & $\downarrow$ & $\begin{array}{l}\text { Regulate the expression of MAP3K7, a kinase able to activate NF- } \mathrm{KB} \text { circuit to } \\
\text { enhance cell proliferation and cycle procession and hinder apoptosis }\end{array}$ & [69] \\
\hline $\operatorname{miR}-153$ & $\downarrow$ & Regulates the expression of BCL2 and MCL1 & {$[55,70]$} \\
\hline miR-194 & $\downarrow$ & $\begin{array}{l}\text { Increases the therapeutic action of MDM2 inhibitors in vitro and in vivo by } \\
\text { enhancing their p53-activating effects }\end{array}$ & [71] \\
\hline miR-203 & $\downarrow$ & Regulates the Jagged1-Notch1 signaling pathway & {$[72,73]$} \\
\hline miR-296 & $\downarrow$ & $\begin{array}{l}\text { Targets high-motility group At-hook gene } 1 \text { (HMGA1) protein leading to a } \\
\text { decrease in cell proliferation and invasion }\end{array}$ & {$[55,74]$} \\
\hline $\operatorname{miR}-373$ & $\uparrow$ & $\begin{array}{l}\text { Enhances cell migration and invasion in vitro and in vivo by suppression } \\
\text { of CD44 }\end{array}$ & {$[55,75]$} \\
\hline $\operatorname{miR}-410$ & $\uparrow$ & $\begin{array}{l}\text { Targets KLF10 via activating PTEN/PI3K/AKT pathway, thus enhancing cell } \\
\text { proliferation, cell cycle progression and apoptosis inhibition in both in vitro } \\
\text { and in vivo }\end{array}$ & [76] \\
\hline miR-500 & $\downarrow$ & $\begin{array}{l}\text { Inhibits cellular proliferation, migration, invasion and adhesion and enhances } \\
\text { cells apoptosis }\end{array}$ & {$[55,77]$} \\
\hline
\end{tabular}

$\uparrow$ up-regulated; $\downarrow$ down-regulated; MAP, mitogen-activated protein; NF- $\mathrm{kB}$, nuclear factor kappa-light-chain-enhancer of activated B cells; BMSCs, bone marrow stromal cells; IL, interleukin; miR, microRNA; PTEN, phosphatase and tensin homolog; E2F1, E2F Transcription Factor 1; TSC1, Tuberous sclerosis proteins 1; mTOR, mechanistic target of rapamycin; MDM2, mouse double minute 2 homolog; PI3K, Phosphoinositide 3-kinase; PHLPP2, PH domain and leucine rich repeat protein phosphatase 2. 
Some of the well-characterized miRNAs that can distinguish MM-free control from MM and MGUS cases with specificity and sensitivity between $80 \%$ and $90 \%$ are the upregulated miR-34a and the down-regulated let-7e [78]. Similarly, high levels of miR-125b-5p, miR-29a and miR-4449, as well as low expressions of miR-30d and miR-203 were reported as potential biomarkers $[67,72,79-81]$. Interestingly, particular miRNAs, such as miR-125b-5p, were specifically detected in the more advanced extramedullary phase of MM [67].

In addition to their diagnostic potentials, miRNAs showed prognostic significance in MM. For instance, a low expression level of miR-15a was associated with a markedly shorter progression-free survival (PFS) and OS [59]. Meanwhile, MM patients with high miR-194 showed higher OS [82]. The overexpression of miR-17 and miR-886-5p was linked to a low OS [83]. Likewise, the MM cases revealing low levels of miR-410 and miR-19a experienced a low PFS and OS [76,84]. In contrast, the downregulation of miR-153, miR-490, miR-500 and miR-642 expression was correlated with better event-free survival [55]. In addition to serum or plasma miRNAs, circulatory exosomal miRNAs such as let-7b and miR-18a possess a prognostic role in MM by predicting the progression of the disease [85].

\subsection{Telomeres and Activity of Telomerase}

Telomeres are nucleoprotein structures that exist at the end of chromosomes and are crucial for protecting chromosomes from degradation [86]. To ensure chromosomal stability and integrity, telomeres form a cap at the chromosome ends, protecting the ends of chromosome arms from inappropriate DNA repair mechanisms and preventing the degradation of genes near the chromosome ends [86]. Telomerase is a ribonucleoprotein complex that serves as a template for the addition of telomeric repeats onto the chromosome ends [87]. Telomeres shorten with every round of cell division and the cells will undergo senescence and apoptosis once the telomeres reach a critical length reduction, thus limiting the proliferation and differentiation of various types of cells [88]. However, in malignant cells, shortened telomeres do not stimulate senescence. In fact, altered telomeres' architecture and physical properties such as telomerase reverse transcriptase (TERT) mutations, rearrangements and TERT promoter methylation were found to contribute to maintaining malignant cell proliferation and immortalization [89,90]. All such events suggested a significant role of telomere maintenance in unlimited cell proliferation and the tumorigenesis of malignancies [91].

MM patients have longer telomeres compared to the control [92,93]. In MM, a higher TERT amplification was detected and presented a significant association with poor prognosis of the disease [94]. A recent study by Aline et al. compared, in a longitudinal prospective study, the 3D telomeric architecture including telomere intensity, numbers, aggregate and nuclear volume in BM samples from patients with MGUS, SMM or MM, with a minimum follow-up of 5 years. Interestingly, alterations of the telomere structure were specific to different phases of MM and correlated with the aggressiveness of the disease [95]. For instance, there was a substantial increase in telomere numbers in MGUS, when compared with MM. Meanwhile, total telomere intensity and nuclear volume were significantly higher in SMM compared with both MGUS and MM [95]. Furthermore, the intensification of all or some of the above-mentioned telomere parameters was correlated with SMM with a high risk of progression and MM with progressive disease [95]. Other studies have linked the risk, outcome, prognosis, disease heterogeneity, cytogenetic status and OS in MM cases with telomerase activity and telomere length $[92,96,97]$, indicating the potential diagnostic and prognostic properties of telomere in MM.

\subsection{Extracellular Matrix (ECM) Proteins}

Crucial to MM cell proliferation, prognosis and drug resistance is the interaction between BM microenvironments that consist of cellular and non-cellular components [98]. The cellular part consists of various hematopoietic and non-hematopoietic cells such as stromal cells, endothelial cells, osteoclasts and osteoblasts, while the non-cellular component includes an extracellular matrix (ECM) and other proteins such as cytokines, growth factors 
and chemokines [98]. In MM, an ECM was found to be remodeled at the gene and protein levels in both MGUS and MM to allow the development of a lenient microenvironment for tumor growth [99]. Various ECM proteins were specifically expressed at different phases of $\mathrm{MM}$, thus representing a potential diagnostic and prognostic tool (Figure 4). For instance, the following ECM proteins: ANXA2 and LGALS1 were expressed more in MM and their abundancy was allied to a decreased OS [99]. Similarly, other proteins associated with cell adhesion, such as laminin subunit beta-1 (encoded by LAMB1) and integrin subunit alpha 9 (encoded by ITGA9), were dysregulated in MM where both LAMB1 and ITGA9 showed prognostic value and clinical correlation in MM patients [100].

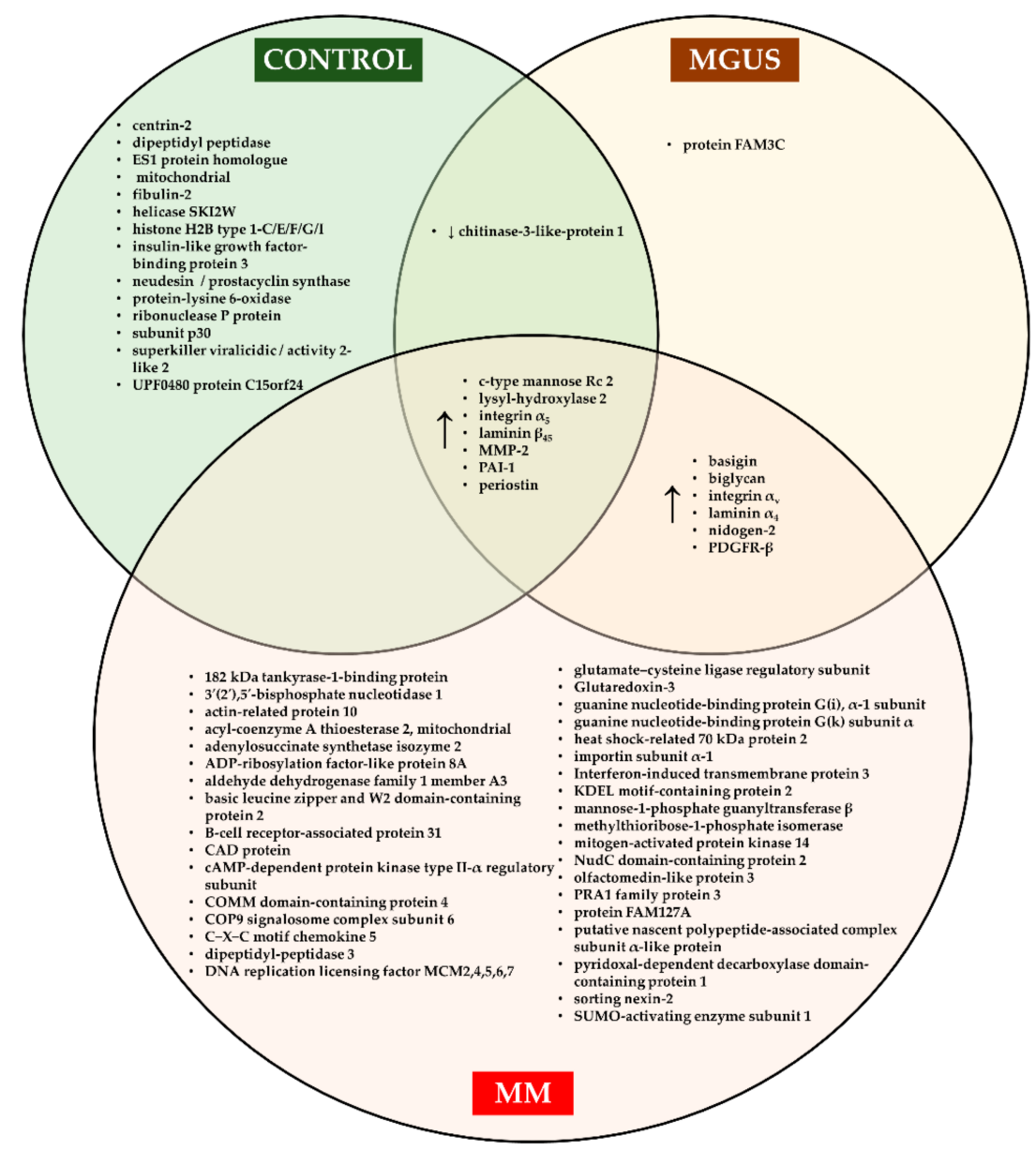

Figure 4. Extracellular matrix proteins that are expressed at different phases of multiple myeloma.

ECM proteins are synthesized by BM stromal cells, which are nonhematopoietic, multipotent progenitor cells that are genetically and functionally altered during the progression of MM [101]. Among BM stromal cells, fibroblasts were shown to support the transition of MGUS to MM [102]. Proteome profiling of BM fibroblasts identified specific proteins acting as biomarkers for the diagnosis/prognosis of MM, where some of these protein markers were characterized to possibly contribute to the transition from MGUS to MM [103]. This may open the door to the development of a risk assessment strategy based on the state of the tumor microenvironment. Though, further research focusing on validating the sensitivity and specificity of these markers is required.

\subsection{Circulatory Tumor Cells and DNA}

Circulatory tumor cells (CTCs) are released into the peripheral circulation from the primary site of the tumor. CTCs were found to exist in MM, representing malignant PCs translocating from the BM to the bloodstream. CTCs are emerging as potential biomarkers 
for MM, where several studies have reported their prognostic roles in SMM and newly diagnosed and relapsed MM (Table 2). The similarity in genetic profiling between CTCs and malignant PCs in the BM suggested that these markers be used for frequent diagnostic and prognostic evaluations rather than the conventional invasive BM biopsies. For instance, deep sequencing of matched BM and peripheral blood samples of MM cases showed that MM cells were located in the peripheral blood of $96 \%$ of the patients, and there was a direct link between the myeloma clone levels in the peripheral blood and the BM [104]. Moreover, $100 \%$ of the clonal mutations in the BM samples were verified in CTCs, and $99 \%$ of the clonal mutations in CTCs were observed in the BM samples, according to an investigation of eight cases of matched BM and peripheral blood samples [105].

Table 2. Circulatory tumor cells and their potential prognostic role in SMM and newly diagnosed and relapsed MM.

\begin{tabular}{|c|c|c|c|}
\hline Study Features & Level/Parameter & Diagnostic/Prognostic Value & Ref. \\
\hline $\begin{array}{l}91 \text { SMM patients at risk of } \\
\text { progression }\end{array}$ & PCs $>5000 \times 10^{6} / \mathrm{L}$ & $\begin{array}{ll}\text { - } & \uparrow \text { progression to active disease within two years of } \\
& \text { diagnosis compared to controls } \\
\text { - } \quad \downarrow \text { median time to progression from } 57 \text { to } \\
12 \text { months independent of M protein levels } \\
\text { - } \quad \downarrow \text { OS from } 148 \text { to } 49 \text { months }\end{array}$ & [106] \\
\hline 100 SMM patients & $\geq 150$ circulating PCs & $\begin{array}{l}\text { - Circulating PCs had } 78 \% \text { positive predictive value } \\
\text { of progression to MM with } 97 \% \text { specificity } \\
\text { - } \quad \text { Median time to progression of } 9 \text { months compared } \\
\text { to not reached for patients with } \leq 150 \text { CTCs }\end{array}$ & [107] \\
\hline $\begin{array}{l}157 \text { newly diagnosed MM } \\
\text { patients }\end{array}$ & $\geq 400$ circulating PCs & $\begin{array}{ll}- & \uparrow \text { PCs proliferation and adverse cytogenetics } \\
- & \downarrow \text { Median OS from } 26 \text { to } 14 \text { months } \\
- & \downarrow \text { Median time-to-next-treatment to } 32 \text { months } \\
& \text { from not reached in patients with }<400 \text { circulating } \\
& \text { PCs } \\
\text { - } & \uparrow \text { ISS stage, creatinine and BM PC percentage }\end{array}$ & [108] \\
\hline $\begin{array}{c}225 \text { newly diagnosed MM } \\
\text { elderly patients }\end{array}$ & $\begin{array}{c}\text { Percentage of } \\
\text { differentiated PCs }\end{array}$ & $\begin{array}{l}\text { PFS and OS were low with less and intermediate } \\
\text { differentiation stages of PCs }\end{array}$ & [109] \\
\hline $\begin{array}{l}647 \text { previously treated } \\
\text { MM patients }\end{array}$ & $\geq 100$ circulating PCs & $\begin{array}{l}\text { - } \quad \text { In patients with plateaued disease, } \downarrow \text { median } \\
\text { survival to } 22 \text { months from not reached } \\
\text { - } \quad \text { In patients with active relapsing disease, } \downarrow \text { median } \\
\text { survival from } 33 \text { to } 12 \text { months }\end{array}$ & [108] \\
\hline $\begin{array}{l}42 \text { relapsed and refractory } \\
\text { MM patients }\end{array}$ & $\begin{array}{l}\text { Presence of pretreatment } \\
\text { circulating PCs }\end{array}$ & $\begin{array}{ll}\text { - } & \downarrow \text { median time for progression from } 456 \text { to } \\
& 218 \text { days } \\
\text { - } & \text { No difference in OS }\end{array}$ & [110] \\
\hline Patients undergoing ASCT & $\begin{array}{l}\text { Presence of circulating } \\
\text { PCs }\end{array}$ & $\begin{array}{ll}\text { - } & \downarrow \text { median PFS from } 29.6 \text { to } 15.1 \text { months } \\
\text { - } & \downarrow \text { median OS to } 41 \text { months from not reached }\end{array}$ & [111] \\
\hline $\begin{array}{l}264 \text { newly diagnosed } \\
\text { plasma cell neoplasms } \\
\text { patients }\end{array}$ & $\begin{array}{l}\text { Presence of circulating } \\
\text { PCs }\end{array}$ & $\begin{array}{l}\text { - Higher numbers of CTCs were associated with } \\
\text { higher levels of BM infiltration, more adverse } \\
\text { prognostic features, shorter time for MGUS to MM } \\
\text { progression and shorter survival }\end{array}$ & [112] \\
\hline
\end{tabular}

$\uparrow$ upregulated; $\downarrow$ downregulated; PCs, plasma cells; MM, multiple myeloma; SMM, smoldering multiple myeloma; CTCs, circulatory tumor cells; OS, overall survival; BM, bone marrow; PFS, progression free survival; ASCT, autologous stem cell transplantation.

The sequencing of protein-coding exons, e.g., KRAS, BRAF and PIK3CA, in circulating tumor DNA (ctDNA) samples from MM patients revealed that it predicted $96 \%$ of mutations detected in matched BM-derived tumor DNA samples with $>98 \%$ specificity [113]. Likewise, paired BM and ctDNA samples from $48 \mathrm{MM}$ cases showed that out of 128 mutations noted in MM, 38 mutations were observed in both the BM and ctDNA samples. Meanwhile, 59 mutations were found in the BM only [114]. The compatibility found in CTCs and BM cells supports the utilization of CTCs as a replacement for BM biopsy. Though, there are still some considerable discrepancies in the genetic profiles of 
the BM sample and peripheral CTC populations induced by the heterogeneous character of MM, which requires more clinical investigations to enhance CTCs' sensitivity as a MM biomarker.

Circulating DNA was shown to significantly increase in the peripheral circulation in several pathological conditions, including cancer. The DNA can be found in either a free form, i.e., cell-free DNA (cfDNA), or in the form of ctDNA. CfDNA is usually released from the cancer cells, thereby possessing the same genetic alterations in the primary tumor cells. The utilization of cfDNA as a prognostic tool in MM has been investigated [115]. The increase in cfDNA was correlated with markedly poor OS. On the other hand, low levels of cfDNA following chemotherapy were associated with an enhanced PFS [116]. Additionally, combining both CTCs and cfDNA analysis can be complementary in replacing BM biopsies to track clonal heterogeneity in MM [117].

\subsection{Genomic Markers}

Cytogenic alternations were included in the revised version of the ISS (Figure 3), indicating their significance in MM assessment. Several other chromosomal translocations and mutations were further reported that can be utilized as biomarkers in MM. These genetic alterations were found to be associated with chemotherapy-induced peripheral neuropathy [118], correlating with the outcome and survival of MM patients [119-125] and indicating the clinical response to treatment [126,127].

\subsection{Proteomic Markers}

Deregulation of protein expression was reported in MM patients compared to nonmalignant samples, demonstrating their diagnostic and/or prognostic potentials. Several studies showed a differential expression of various proteins such as haptoglobin, kininogen 1, transferrin, serum amyloid A protein, plasma kallikrein, integrin alpha-11, apolipoprotein A-I, sulfhydryl oxidase 1 and isoform-1 of multimerin-1 in the sera of MM patients [128-130].

Interestingly, the up-regulation of proteins associated with protein folding and proteasome functions, including proteasome activator complex subunit 1 , heat shock protein 90, stress-induced-phosphoprotein 1 and protein disulfide-isomerase, was correlated with refractory response bortezomib-based therapy [131], whereas the proteins functioning during inflammation and apoptosis were down-regulated in patients not responding to bortezomib-based therapy [132]. The up-regulation of other proteins, such as Zinc-a-2glycoprotein, amyloid-A protein and vitamin D-binding protein, was found to play a role in the prediction of a thalidomide response in MM patients [133]. Collectively, the proteomic markers exhibited useful potentials as diagnostic and prognostic tools. However, they still need systematic validation to be deployed in clinical settings.

\subsection{Immunological Markers}

The introduction of several immune-based approaches in treating MM has been revolutionized over the years to become one of the most investigated areas for novel MM therapeutics. Recently approved drugs such as elotuzumab [134] and daratumumab [135], in addition to other immunomodulatory therapies under investigation, including chimeric antigen receptor (CAR) T-cell therapy, are showing great therapeutic potential. Though, there is still a need to validate these and other therapeutic agents in order to have consistency in their effectiveness across a wide range of patients. To achieve this, efficient predictive immune biomarkers are required. Yet, few immune markers have been validated in MM. These markers include CD38, CD55 and CD59. The pretreatment expression of CD38 was correlated with a better outcome to daratumumab, while lack of response and tumor progression was associated with expression of both CD55 and CD59 [136]. Additionally, high-density neutrophils isolated from the peripheral blood of newly diagnosed MM patients showed up-regulation of CD64 and down-regulation of CD16, which were associated with increased immune-suppression [137]. Furthermore, high CD64 in MM 
patients receiving bortezomib, thalidomide and dexamethasone were associated with an inferior median OS [137]. Table 3 summarizes the results of a few studies that examined the value of immune biomarkers as potential prognostic tools in MM.

Table 3. Immune biomarkers and their prognostic role in MM.

\begin{tabular}{|c|c|c|c|}
\hline Study Features & Immune Biomarker & Prognostic Value & Ref. \\
\hline $65 \mathrm{MM}$ and cancer-free cases & $\begin{array}{l}\text { MCP-3, VEGF, FGF-2 and } \\
\text { TGF- } \alpha\end{array}$ & $\begin{array}{l}\text { Low levels of these biomarkers were detected among future } \\
\text { MM patients and increased risk of progression }\end{array}$ & [138] \\
\hline $\begin{array}{l}268 \text { B-cell lymphomas patients } \\
\text { (including } 76 \mathrm{MM} \text { patients) }\end{array}$ & $\begin{array}{l}\text { MCP-3, FGF-2, TGF- } \alpha, \\
\text { MIP- } 1 \alpha \text {, VEGF, fractalkine }\end{array}$ & Biomarkers showed an inverse association with risk of $\mathrm{MM}$ & [139] \\
\hline $\begin{array}{l}177 \text { MM patients undergone } \\
\text { ASCT from } 2007 \text { to } 2016\end{array}$ & $\begin{array}{l}\text { oligoclonal immunoglobulin } \\
\text { bands, i.e., clonal isotype } \\
\text { switch (CIS) }\end{array}$ & $\begin{array}{ll}\text { - } & \text { CIS after ASCT was correlated with increased PFS to } 52.2 \\
\text { from } 36.6 \text { months and OS to } 75.1 \text { from } 65.4 \text { months } \\
\text { - } & \text { Different isotype of CIS was found in relapsed patients } \\
\text { - } & \text { CIS was associated with decreased CD8 T-cell } \\
\text { percentages and a higher CD4/CD8 ratio }\end{array}$ & [140] \\
\hline $\begin{array}{l}372 \text { newly diagnosed } \mathrm{MM} \\
\text { patients }\end{array}$ & $\begin{array}{l}\text { ALC to AMC ratio in the } \\
\text { peripheral blood }\end{array}$ & $\begin{array}{l}\text { ALC/AMC } \geq 3.6 \text { was associated with superior PFS ( } 43 \text { versus } \\
24 \text { months) and OS ( } 62 \text { versus } 48 \text { months) compared with } \\
\text { ALC/AMC }<3.6\end{array}$ & [141] \\
\hline $\begin{array}{l}201 \text { newly diagnosed MM } \\
\text { patients }\end{array}$ & LMR and u-Ig levels & $\begin{array}{l}\text { ORR and OS were decreased in cases with LMR }<3.6 \text { and } \mathrm{u} \text {-Ig } \\
\text { decreased by } \geq 2 \text { items }\end{array}$ & [142] \\
\hline $\begin{array}{l}285 \text { newly diagnosed } \mathrm{MM} \\
\text { patients }\end{array}$ & LMR levels & $\begin{array}{l}\text { - } \quad \text { Patients with LMR } \leq 4.2 \text { had poorer OS and PFS than } \\
\text { those with LMR }>4.2 \\
\text { LMR less than } 4.2 \text { is an independent predictor for the OS } \\
\text { and PFS }\end{array}$ & [143] \\
\hline $\begin{array}{l}130 \text { MM patients receiving } \\
\text { Mel200 and ASCT }\end{array}$ & $\begin{array}{l}\mathrm{ALC}, \mathrm{AMC}, \mathrm{ANC}, \mathrm{LMR}, \mathrm{NLR} \\
\text { and Ig }\end{array}$ & $\begin{array}{ll}\text { - } & \text { Low ALC and AMC had a low TFS (18 versus } 23 \text { months) } \\
\text { and (13 versus } 25 \text { months), respectively } \\
\text { - } & \text { Low LMR had a decreased TFS (16 versus } 52 \text { months) } \\
\text { - } & \text { Patients with two or three suppressed Ig levels had low } \\
\text { TFS (17 versus } 51 \text { months) } \\
\text { - } \quad \text { Poor (low LMR and } 2-3 \text { suppressed Ig) and good (high } \\
\text { LMR and 0-1 suppressed Ig) risk groups showed a } \\
\text { median TFS of } 7.5 \text { versus } 79 \text { months, respectively }\end{array}$ & [144] \\
\hline $\begin{array}{l}150 \mathrm{MM} \text { patients treated with } \\
\text { BCD }\end{array}$ & $\begin{array}{l}\text { (neutrophils }+ \\
\text { monocytes)/lymphocytes } \\
\text { ratio (NMLR) }\end{array}$ & $\begin{array}{l}\text { - } \quad \text { Low NMLR was associated with decreased } \\
\beta 2 \text {-microglobulin, serum creatinine and calcium and } \\
\text { increased partial response } \\
\text { - Low NMLR was correlated with a superior median PFS } \\
\text { (24.0 versus } 15.5 \text { months) } \\
\text { NMLR was an independent predictor of PFS including } \\
\text { non-high-risk cytogenetics }\end{array}$ & [145] \\
\hline $\begin{array}{l}102 \text { newly diagnosed } \\
\text { MM patients }\end{array}$ & ALC and LMR & $\begin{array}{ll}\text { - } & \text { ALC }<1.43 \times 109 / \mathrm{L} \text { and } \mathrm{LMR}<3.7 \text { predicted shorter OS } \\
\text { - } & \text { ALC and LMR were independent predictors for OS }\end{array}$ & [146] \\
\hline $\begin{array}{l}45 \text { MM stage I (MMI) and } 50 \\
\text { MM stage III (MMIII) }\end{array}$ & IKZF1 and IKZF3 of T-cells & $\begin{array}{l}\text { High IKZF3, but not IKZF1, correlates with superior OS in } \\
\text { MMIII treated with immunomodulatory drugs }\end{array}$ & [147] \\
\hline $\begin{array}{l}685 \text { progressing or stable MGUS } \\
\text { patients }\end{array}$ & $\begin{array}{l}\text { Serum protein and } \\
\text { monoclonal Ig, free light } \\
\text { chains and light chains }\end{array}$ & $\begin{array}{l}\text { Progressive MGUS was associated with } \operatorname{IgA},>15 \mathrm{~g} / \mathrm{L} \\
\text { monoclonal spike, skewed }(<0.1 \text { or }>10) \text { serum free light chains } \\
\text { ratio }\end{array}$ & [148] \\
\hline
\end{tabular}

MCP-3, monocyte chemotactic protein-3; MIP-1 $\alpha$, macrophage inflammatory protein-1 alpha; VEGF, vascular endothelial growth factor; FGF-2, fibroblast growth factor-2; TGF- $\alpha$, transforming growth factor-alpha; ASCT, autologous stem cell transplantation; PFS, progressionfree survival; OS, overall survival; ALC, absolute lymphocyte count; AMC, absolute monocyte count; LMR, lymphocyte-to-monocyte ratio; $\mathrm{u}-\mathrm{Ig}$, uninvolved immunoglobulin; ANC, absolute neutrophil count; NLR, neutrophil to lymphocyte ratio; TFS, treatment-free survival; Ig, immunoglobulin; BCD, bortezomib, cyclophosphamide and dexamethasone; ORR, objective response rate.

Future potential immune biomarkers in MM include neoantigens, a group of antigenic products of somatic mutations that are specific to tumors [149]. The tumor-specific neoantigens do not induce autoimmune toxicity, therefore, they are utilized as drug targets for cancer immunotherapies based on the continuously reported neoantigen-specific $T$ cell responses $[150,151]$. Although a positive association between neoantigens and clinical responses in several cancers has been reported, the potential role of neoantigens in MM as prognostic biomarkers is still lacking. A recent study suggested high somatic mutation and neoantigen burden were correlated with decreased PFS in MM patients [152]. Addi- 
tionally, relapsed MM patients demonstrated an increased neoantigen load compared to newly diagnosed patients [153]. Furthermore, the majority of the neoantigens identified by Perumal et al. [153] were not shared between patients and are highly patient-specific. Therefore, future studies are necessary to characterize ideal immune markers to efficiently identify the patients who would ideally benefit from immunotherapy.

\section{Advanced Methodologies in Next-Generation Biomarkers}

In addition to exploring new markers, clinicians and researchers are further conserving the utilization of emerging diagnostic/prognostic techniques and procedures that can be utilized in managing MM (Table 4).

Table 4. Advanced methodologies and their potential roles in diagnosis and prognosis of MM.

\begin{tabular}{|c|c|c|c|}
\hline Method/Technique & Features & Diagnostic/Prognostic Value & Ref. \\
\hline $\begin{array}{l}\text { Multiparameter Flow } \\
\text { Cytometry (MPC) }\end{array}$ & $\begin{array}{l}\text { Panels of fluorochrome-conjugated } \\
\text { antibodies with distinct fluorescence } \\
\text { excitation and emission characteristics } \\
\text { bind specifically to particular cell } \\
\text { phenotypes. Fluorochromes become } \\
\text { excited by different lasers to define a } \\
\text { high-content molecular signature for } \\
\text { each cell }\end{array}$ & 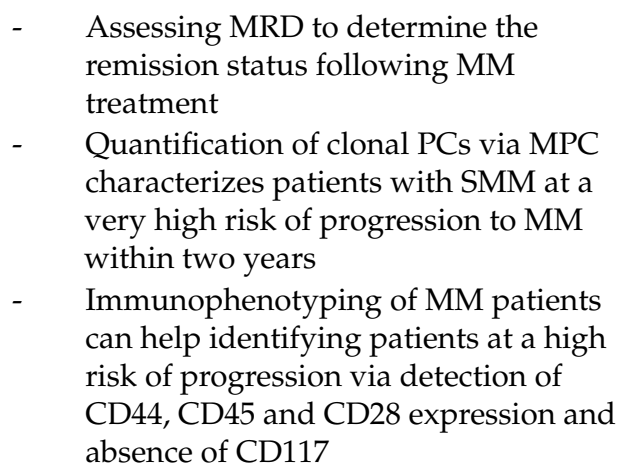 & [154-157] \\
\hline $\begin{array}{l}\text { Next-generation } \\
\text { sequencing (NGS) }\end{array}$ & $\begin{array}{l}\text { A reversible-terminator-based } \\
\text { sequencing that can read up to } 300 \text { bps } \\
\text { with paired-end sequencing. NGS can } \\
\text { identify chimeric DNA molecules } \\
\text { where the two ends originate from } \\
\text { different chromosomes of chromosomal } \\
\text { segments, e.g., a translocation } \\
\text { breakpoint }\end{array}$ & 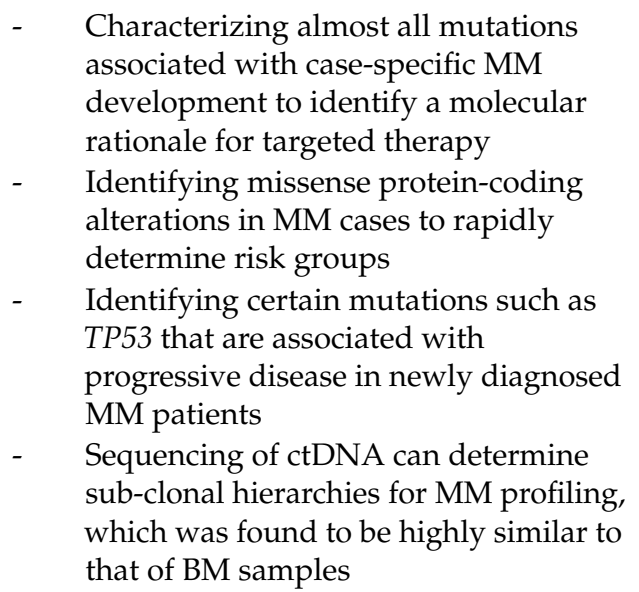 & [160] \\
\hline \multirow{4}{*}{ Liquid/blood biopsy } & \multirow{4}{*}{$\begin{array}{l}\text { A novel minimally invasive technique } \\
\text { for characterizing MM phases and } \\
\text { progression when compared to BM } \\
\text { biopsy via detecting biomarkers in the } \\
\text { peripheral circulation }\end{array}$} & $\begin{array}{l}\text { Identifying circulating extracellular } \\
\text { vehicles (EVs) to be used for } \\
\text { monitoring disease burden, disease } \\
\text { progression and development of MDR } \\
\text { in MM }\end{array}$ & [160] \\
\hline & & $\begin{array}{l}\text { Detecting CTCs in peripheral blood of } \\
\text { MM cases can help in risk stratifying } \\
\text { and early diagnosis of MM }\end{array}$ & [162] \\
\hline & & $\begin{array}{l}\text { Qualitative assessment of cytogenetic } \\
\text { alterations found in ctDNA may help } \\
\text { in evaluating overtime clonal evolution } \\
\text { of MM }\end{array}$ & [163] \\
\hline & & $\begin{array}{l}\text { Analyzing EVs content was shown to } \\
\text { have a prognostic value and might } \\
\text { predict drug resistance in MM cases }\end{array}$ & {$[85,164]$} \\
\hline
\end{tabular}


Table 4. Cont.

\begin{tabular}{|c|c|c|c|}
\hline Method/Technique & Features & Diagnostic/Prognostic Value & Ref. \\
\hline $\begin{array}{l}\text { Allele-specific } \\
\text { oligonucleotide } \\
\text { (ASO)-qPCR }\end{array}$ & $\begin{array}{l}\text { A short oligonucleotide complementary } \\
\text { to sequence of a variable target DNA. It } \\
\text { is usually labeled with a radioactive, } \\
\text { enzymatic or fluorescent tag. It is } \\
\text { highly sensitive to detect a difference of } \\
\text { as little as one base in the target's } \\
\text { sequence }\end{array}$ & 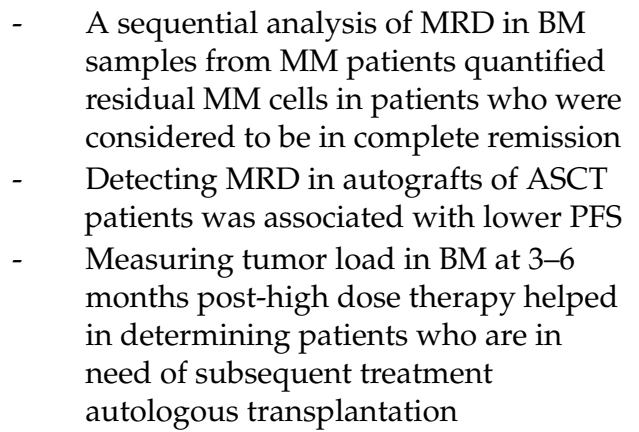 & [166] \\
\hline
\end{tabular}

PCs, plasma cells; MM, multiple myeloma; CTCs, circulatory tumor cells; BM, bone marrow; PFS, progression-free survival; ASCT, autologous stem cell transplantation; MRD, minimal residual disease; ctDNA, circulatory DNA.

\subsection{Flow Cytometry}

Due to its unique properties in terms of cell analysis, flow cytometry (FC) has swiftly moved from fundamental research to clinical facilities. Flow cytometry technology is currently used in cancer research for a variety of purposes, including the identification of tumor cells, DNA aneuploidy, analysis of cell proliferation and immunophenotyping [154]. In MM, specific markers were utilized to determine the remission status following MM treatment via assessing the minimal residual disease (MRD). The magnitude of the treatment response is commonly evaluated based on paraprotein levels representing residual disease that may contribute to relapse. The PFS and OS were longer in newly diagnosed MM patients with negative MRD detected using FC, suggesting FC as a powerful prognostic tool [155]. Similarly, treated MM cases without MRD after ASCT had a superior PFS and OS compared to MRD positive cases [168]. Interestingly, MRD was shown to be an independent factor predicting complete remission in patients after therapy $[169,170]$. The more advanced next-generation flow cytometry using EuroFlow can detect low levels of MRD that help in sensitive MRD monitoring and more efficient predictive capabilities [171-174].

\subsection{Next-Generation Sequencing (NGS)}

With the development of advanced sequencing technology, next-generation sequencing (NGS) has been broadly applied in clinical oncology in the last decade. NGS is extremely helpful when it comes to identifying novel cancer mutations and characterizing molecular rationale for targeted therapy. Unlike traditional sequencing, NGS can fully sequence almost all mutations for thousands of genes at a lower cost. Yet, there are still some challenges that must be overcome for easier utilization of NGS in cancer management. More flexible throughput, as well as feasible data analysis and interpretation, are potential areas of improvement. NGS has been used in the determination of MRD in MM [175-177]. Negative MRD detected by deep sequencing revealed a significantly longer progression time (80 months versus 31 months) and a superior OS (not reached versus 81 months) compared to MRD positive. Likewise, using NGS, patients with less than 10-6 tumor cells showed a three-year PFS at $83 \%$ versus $53 \%$ for patients with more than $10-6$ cells at lenalidomide maintenance following chemotherapy [178]. In newly diagnosed MM and SMM patients treated with chemotherapy followed by lenalidomide, the 18 months PFS was markedly different in MRD-negative and MRD-positive patients ( $100 \%$ versus $84 \%$, respectively) [179]. NGS played a significant role in determining MM mutational heterogenicity indicated by the variety of mutated genes and subclonality observed in myeloma disease, thus supporting the importance of developing case-specific and individualized treatment plans for MM cases. 


\subsection{Liquid or Blood Biopsy}

As we have highlighted earlier the increasing significance of CTCs and cfDNA in the diagnosis and prognosis of MM in Section 3.5, collecting these biomarkers from peripheral circulation is achieved via liquid biopsy. It represents a promising novel minimally invasive technique for the detection of disease phases and progression when compared to BM biopsy. Even though BM biopsy is frequently used in MM cases, it still represents a burden due to the associated severe pain, tissue injury and potential biopsy errors resulting in it being not applicable for frequent utilization for continuous and proper disease monitoring as well as accurate assessment. Therefore, a liquid biopsy could represent a superior technique due to the high similarity, highlighted earlier in this review, between both procedures with regard to myeloma clone levels and clonal mutations [105]. Moreover, a liquid biopsy is less invasive, and its possible frequent applications could account for MM clonal heterogeneity that might be missed by a single BM biopsy.

\subsection{Allele-Specific Oligonucleotide qPCR}

MRD can be further assessed with high sensitivity using an allele-specific oligonucleotide qPCR (ASO-qPCR) via detecting specific IgH gene rearrangements in MM PCs [172] A remarkably higher number of tumor cells was detected using an ASO-qPCR in samples from MM patients with progressive disease compared with patients in remission [167]. An ASO-qPCR could further be used in evaluating tumor burden and PFS subsequent to a BM transplant [180]. When comparing both FC and an ASO-qPCR for the assessment of MRD, a substantial correlation was observed in MRD quantitation in both techniques [181]. Among 170 MM patients, the cases with higher MRD showed a markedly lower PFS and OS [181]. Despite the feasible and easy applicability of an ASO-qPCR, it is only applicable to about $42 \%$ of MM cases.

\section{Conclusions and Future Directions}

For decades, conventional biomarkers such as $\mathrm{M}$ protein, $\beta 2$ microglobulin, albumin, cytogenic alterations and bone lesions assessed using serum protein electrophoresis, FISH and imaging were used to diagnose and risk-stratify MM. These markers are currently established and incorporated in diagnosis and staging guidelines. Though, the rise in the number of $\mathrm{MM}$ cases further expanded the research exploring and developing better diagnostic or prognostic biomarkers. The next-generation biomarkers, including miRNAs, angiogenic markers, ECM proteins, telomeres and telomerase activity have shown great potential in MM diagnosis and prognosis. Moreover, competent immune markers are now emerging to enhance immunotherapy effectiveness via promoting predictive values and customizing treatment plans following proper assessment. Likewise, the utilization of new methodologies in MM diagnosis and risk assessment is critical. In this review, we discussed the significance of employing flow cytometry, NGS, ASO-qPCR and blood biopsy as novel diagnostic and prognostic procedures in MM. Blood biopsy, for instance, could examine the serum levels of CTCs, miRNAs and cfDNA in the peripheral circulation, which provide an advantageous early, frequent and less painful assessment of the disease status compared to the invasive BM biopsy. Although the novel biomarkers show great potential, they have been studied in a small cohort of MM cases. Therefore, for them to be adopted in clinical settings, thorough evaluation and validation in more clinical trials with a large sample size are still required.

Author Contributions: Conceptualization, S.D.; writing-original draft preparation, A.M.S.; writing —review and editing, S.D. and S.L.T. All authors have read and agreed to the published version of the manuscript.

Funding: This research received no external funding.

Conflicts of Interest: The authors declare no conflict of interest. 


\section{References}

1. Kazandjian, D.; Mailankody, S.; Korde, N.; Landgren, O. Smoldering multiple myeloma: Pathophysiologic insights, novel diagnostics, clinical risk models, and treatment strategies. Clin. Adv. Hematol. Oncol. 2014, 12, 578-587.

2. Rajkumar, S.V.; Kumar, S. Multiple myeloma: Diagnosis and treatment. Mayo Clin. Proc. 2016, 91, 101-119. [CrossRef]

3. Bakheet, O.S.E.; Leong, C.F.; Ithnin, A.; Wahid, S.F.A. IgD-kappa multiple myeloma. Case report and brief review of the literature. N. Z. J. Med. Lab. Sci. 2016, 70, 8-11.

4. Low, S.F.; Mohd Tap, N.H.; Kew, T.Y.; Ngiu, C.S.; Sridharan, R. Non secretory multiple myeloma with extensive extramedullary plasmacytoma: A diagnostic dilemma. Iran. J. Radiol. 2015, 12, e11760. [CrossRef]

5. Jemal, A.; Bray, F.; Center, M.M.; Ferlay, J.; Ward, E.; Forman, D. Global cancer statistics. CA Cancer J. Clin. 2011, 61, 69-90. [CrossRef]

6. Phekoo, K.J.; Schey, S.A.; Richards, M.A.; Bevan, D.H.; Bell, S.; Gillett, D.; Møller, H.; Consultant Haematologists; South Thames Haematology Specialist Committee. A population study to define the incidence and survival of multiple myeloma in a National Health Service Region in UK. Br. J. Haematol. 2004, 127, 299-304. [CrossRef] [PubMed]

7. Rajkumar, S.V. Multiple myeloma: 2014 Update on diagnosis, risk-stratification, and management. Am. J. Hematol. 2014, 89, 998-1009. [CrossRef]

8. Ruzafa, J.C.; Merinopoulou, E.; Baggaley, R.F.; Leighton, P.; Werther, W.; Felici, D.; Cox, A. Patient population with multiple myeloma and transitions across different lines of therapy in the USA: An epidemiologic model. Pharmacoepidemiol. Drug Saf. 2016, 25, 871-879. [CrossRef] [PubMed]

9. Pena, C.; Rojas, C.; Rojas, H.; Soto, P.; Cardemil, D.; Aranda, S.; Contreras, C.; La Roca, G.; Russo, M.; Perez, C.; et al. [Survival of 1,103 Chilean patients with multiple myeloma receiving different therapeutic protocols from 2000 to 2016]. Rev. Méd. Chile 2018, $146,869-875$.

10. Andriandi; Kamal, A. F. Survival rate of multiple myeloma patients in Indonesia: A retrospective study in multiple myeloma at a single institution. Ann. Med. Surg. 2019, 41,11-15. [CrossRef]

11. Bolli, N.; Maura, F.; Minvielle, S.; Gloznik, D.; Szalat, R.; Fullam, A.; Martincorena, I.; Dawson, K.J.; Samur, M.K.; Zamora, J.; et al. Genomic patterns of progression in smoldering multiple myeloma. Nat. Commun. 2018, 9, 3363. [CrossRef] [PubMed]

12. Dutta, A.K.; Fink, J.L.; Grady, J.P.; Morgan, G.J.; Mullighan, C.G.; To, L.B.; Hewett, D.R.; Zannettino, A.C.W. Subclonal evolution in disease progression from MGUS/SMM to multiple myeloma is characterised by clonal stability. Leukemia 2019, 33, 457-468. [CrossRef] [PubMed]

13. Bianchi, G.; Anderson, K.C. Understanding biology to tackle the disease: Multiple myeloma from bench to bedside, and back. $C A$ Cancer J. Clin. 2014, 64, 422-444. [CrossRef]

14. Rajan, A.M.; Rajkumar, S.V. Interpretation of cytogenetic results in multiple myeloma for clinical practice. Blood Cancer J. 2015, 5, e365. [CrossRef] [PubMed]

15. Terpos, E.; Ntanasis-Stathopoulos, I.; Gavriatopoulou, M.; Dimopoulos, M.A. Pathogenesis of bone disease in multiple myeloma: From bench to bedside. Blood Cancer J. 2018, 8, 7. [CrossRef] [PubMed]

16. Gran, C.; Uttervall, K.; Borg Bruchfeld, J.; Wallblom, A.; Alici, E.; Gahrton, G.; Nahi, H. Translocation (11;14) in newly diagnosed multiple myeloma, time to reclassify this standard risk chromosomal aberration? Eur. J. Haematol. 2019, 103, 588-596. [CrossRef] [PubMed]

17. Barwick, B.G.; Neri, P.; Bahlis, N.J.; Nooka, A.K.; Dhodapkar, M.V.; Jaye, D.L.; Hofmeister, C.C.; Kaufman, J.L.; Gupta, V.A.; Auclair, D.; et al. Multiple myeloma immunoglobulin lambda translocations portend poor prognosis. Nat. Commun. 2019, 10, 1911. [CrossRef] [PubMed]

18. Chapman, M.A.; Lawrence, M.S.; Keats, J.J.; Cibulskis, K.; Sougnez, C.; Schinzel, A.C.; Harview, C.L.; Brunet, J.P.; Ahmann, G.J.; Adli, M.; et al. Initial genome sequencing and analysis of multiple myeloma. Nature 2011, 471, 467-472. [CrossRef]

19. Lohr, J.G.; Stojanov, P.; Carter, S.L.; Cruz-Gordillo, P.; Lawrence, M.S.; Auclair, D.; Sougnez, C.; Knoechel, B.; Gould, J.; Saksena, G.; et al. Widespread genetic heterogeneity in multiple myeloma: Implications for targeted therapy. Cancer Cell 2014, $25,91-101$. [CrossRef]

20. Bolli, N.; Avet-Loiseau, H.; Wedge, D.C.; Van Loo, P.; Alexandrov, L.B.; Martincorena, I.; Dawson, K.J.; Iorio, F.; Nik-Zainal, S.; Bignell, G.R.; et al. Heterogeneity of genomic evolution and mutational profiles in multiple myeloma. Nat. Commun. 2014, 5, 2997. [CrossRef]

21. Loven, J.; Hoke, H.A.; Lin, C.Y.; Lau, A.; Orlando, D.A.; Vakoc, C.R.; Bradner, J.E.; Lee, T.I.; Young, R.A. Selective inhibition of tumor oncogenes by disruption of super-enhancers. Cell 2013, 153, 320-334. [CrossRef]

22. Delmore, J.E.; Issa, G.C.; Lemieux, M.E.; Rahl, P.B.; Shi, J.; Jacobs, H.M.; Kastritis, E.; Gilpatrick, T.; Paranal, R.M.; Qi, J.; et al. BET bromodomain inhibition as a therapeutic strategy to target c-Myc. Cell 2011, 146, 904-917. [CrossRef] [PubMed]

23. Alexandrov, L.B.; Nik-Zainal, S.; Wedge, D.C.; Aparicio, S.A.; Behjati, S.; Biankin, A.V.; Bignell, G.R.; Bolli, N.; Borg, A.; Borresen-Dale, A.L.; et al. Signatures of mutational processes in human cancer. Nature 2013, 500, 415-421. [CrossRef]

24. Rajkumar, S.V. Multiple myeloma: 2016 update on diagnosis, risk-stratification, and management. Am. J. Hematol. 2016, 91, 719-734. [CrossRef] [PubMed]

25. Rajkumar, S.V.; Dimopoulos, M.A.; Palumbo, A.; Blade, J.; Merlini, G.; Mateos, M.V.; Kumar, S.; Hillengass, J.; Kastritis, E.; Richardson, P.; et al. International Myeloma Working Group updated criteria for the diagnosis of multiple myeloma. Lancet Oncolol. 2014, 15, e538-e548. [CrossRef] 
26. Fechtner, K.; Hillengass, J.; Delorme, S.; Heiss, C.; Neben, K.; Goldschmidt, H.; Kauczor, H.U.; Weber, M.A. Staging monoclonal plasma cell disease: Comparison of the Durie-Salmon and the Durie-Salmon PLUS staging systems. Radiology 2010, 257, 195-204. [CrossRef]

27. Greipp, P.R.; San Miguel, J.; Durie, B.G.; Crowley, J.J.; Barlogie, B.; Blade, J.; Boccadoro, M.; Child, J.A.; Avet-Loiseau, H.; Kyle, R.A.; et al. International staging system for multiple myeloma. J. Clin. Oncol. 2005, 23, 3412-3420. [CrossRef] [PubMed]

28. Kyle, R.A.; Gertz, M.A.; Witzig, T.E.; Lust, J.A.; Lacy, M.Q.; Dispenzieri, A.; Fonseca, R.; Rajkumar, S.V.; Offord, J.R.; Larson, D.R.; et al. Review of 1027 patients with newly diagnosed multiple myeloma. Mayo Clin. Proc. 2003, 78, 21-33. [CrossRef] [PubMed]

29. Chawla, S.S.; Kumar, S.K.; Dispenzieri, A.; Greenberg, A.J.; Larson, D.R.; Kyle, R.A.; Lacy, M.Q.; Gertz, M.A.; Rajkumar, S.V. Clinical course and prognosis of non-secretory multiple myeloma. Eur. J. Haematol. 2015, 95, 57-64. [CrossRef] [PubMed]

30. Zuazo-Gaztelu, I.; Casanovas, O. Unraveling the role of angiogenesis in cancer ecosystems. Front. Oncol. 2018, 8, 248. [CrossRef]

31. Feng, Q.; Guo, P.; Wang, J.; Zhang, X.; Yang, H.C.; Feng, J.G. High expression of SDF-1 and VEGF is associated with poor prognosis in patients with synovial sarcomas. Exp. Ther. Med. 2018, 15, 2597-2603. [CrossRef]

32. Luz, C.C.F.; Noguti, J.; Araujo, L.; Simao Gomes, T.; Mara, G.; Silva, M.S.; Artigiani Neto, R. Expression of VEGF and Cox-2 in patients with esophageal squamous cell carcinoma. Asian Pac. J. Cancer Prev. 2018, 19, 171-177.

33. Zhang, L.; Wang, H.; Li, C.; Zhao, Y.; Wu, L.; Du, X.; Han, Z. VEGF-A/neuropilin 1 pathway confers cancer stemness via activating Wnt/b-catenin axis in breast cancer cells. Cell. Physiol. Biochem. 2017, 44, 1251-1262. [CrossRef] [PubMed]

34. Khan, R.; Sharma, M.; Kumar, L.; Husain, S.A.; Sharma, A. Interrelationship and expression profiling of cyclooxygenase and angiogenic factors in Indian patients with multiple myeloma. Ann. Hematol. 2013, 92, 101-109. [CrossRef] [PubMed]

35. Joshi, S.; Khan, R.; Sharma, M.; Kumar, L.; Sharma, A. Angiopoietin-2: A potential novel diagnostic marker in multiple myeloma. Clin. Biochem. 2011, 44, 590-595. [CrossRef] [PubMed]

36. Fan, F.; Malvestiti, S.; Vallet, S.; Lind, J.; Garcia-Manteiga, J.M.; Morelli, E.; Jiang, Q.; Seckinger, A.; Hose, D.; Goldschmidt, H.; et al. JunB is a key regulator of multiple myeloma bone marrow angiogenesis. Leukemia 2021. [CrossRef]

37. Attar-Schneider, O.; Drucker, L.; Zismanov, V.; Tartakover-Matalon, S.; Rashid, G.; Lishner, M. Bevacizumab attenuates major signaling cascades and eIF4E translation initiation factor in multiple myeloma cells. Lab. Investig. 2012, 92, 178-190. [CrossRef] [PubMed]

38. Khan, R.; Sharma, M.; Kumar, L.; Husain, S.A.; Sharma, A. Cinnamon extract exhibits potent anti-proliferative activity by modulating angiogenesis and cyclooxygenase in myeloma cells. J. Herb. Med. 2016, 6, 149-156. [CrossRef]

39. Guo, H.M.; Sun, L.; Yang, L.; Liu, X.J.; Nie, Z.Y.; Luo, J.M. Microvesicles shed from bortezomib-treated or lenalidomide-treated human myeloma cells inhibit angiogenesis in vitro. Oncol. Rep. 2018, 39, 2873-2880. [CrossRef]

40. Rao, L.; Giannico, D.; Leone, P.; Solimando, A.G.; Maiorano, E.; Caporusso, C.; Duda, L.; Tamma, R.; Mallamaci, R.; Susca, N.; et al. HB-EGF-EGFR signaling in bone marrow endothelial cells mediates angiogenesis associated with multiple myeloma. Cancers 2020, 12, 173. [CrossRef]

41. Lamanuzzi, A.; Saltarella, I.; Frassanito, M.A.; Ribatti, D.; Melaccio, A.; Desantis, V.; Solimando, A.G.; Ria, R.; Vacca, A. Thrombopoietin promotes angiogenesis and disease progression in patients with multiple myeloma. Am. J. Pathol. 2021, 191, 748-758. [CrossRef] [PubMed]

42. Nwabo Kamdje, A.H.; Kamga, P.T.; Simo, R.T.; Vecchio, L.; Seke Etet, P.F.; Muller, J.M.; Bassi, G.; Lukong, E.; Goel, R.K.; Amvene, J.M.; et al. Mesenchymal stromal cells' role in tumor microenvironment: Involvement of signaling pathways. Cancer Biol. Med. 2017, 14, 129-141. [CrossRef] [PubMed]

43. Zhang, X.; Xu, Y.; Liu, H.; Zhao, P.; Chen, Y.; Yue, Z.; Zhang, Z.; Wang, X. HIF-2a-ILK is involved in mesenchymal stromal cell angiogenesis in multiple myeloma under hypoxic conditions. Technol. Cancer Res. Treat. 2018, 17, 1533033818764473. [CrossRef] [PubMed]

44. Hofmann, J.N.; Landgren, O.; Landy, R.; Kemp, T.J.; Santo, L.; McShane, C.M.; Shearer, J.J.; Lan, Q.; Rothman, N.; Pinto, L.A.; et al. A prospective study of circulating chemokines and angiogenesis markers and risk of multiple myeloma and its precursor. JNCI Cancer Spectr. 2020, 4, pkz104. [CrossRef]

45. Saltarella, I.; Morabito, F.; Giuliani, N.; Terragna, C.; Omede, P.; Palumbo, A.; Bringhen, S.; De Paoli, L.; Martino, E.; Larocca, A.; et al. Prognostic or predictive value of circulating cytokines and angiogenic factors for initial treatment of multiple myeloma in the GIMEMA MM0305 randomized controlled trial. J. Hematol. Oncol. 2019, 12, 4. [CrossRef]

46. Teoh, S.L.; Das, S. The role of microRNAs in diagnosis, prognosis, metastasis and resistant cases in breast cancer. Curr. Pharm. Des. 2017, 23, 1845-1859. [CrossRef]

47. Ab Mutalib, N.S.; Othman, S.N.; Mohamad Yusof, A.; Abdullah Suhaimi, S.N.; Muhammad, R.; Jamal, R. Integrated microRNA, gene expression and transcription factors signature in papillary thyroid cancer with lymph node metastasis. PeerJ 2016, 4, e2119. [CrossRef] [PubMed]

48. Ankasha, S.J.; Shafiee, M.N.; Wahab, N.A.; Ali, R.A.R.; Mokhtar, N.M. Post-transcriptional regulation of microRNAs in cancer: From prediction to validation. Oncol. Rev. 2018, 12, 344. [CrossRef]

49. Ghafouri-Fard, S.; Shoorei, H.; Taheri, M. miRNA profile in ovarian cancer. Exp. Mol. Pathol. 2020, 113, 104381. [CrossRef]

50. Soliman, A.M.; Teoh, S.L.; Mahakkanukrauh, P.; Das, S. Role of microRNAs in diagnosis, prognosis and management of multiple myeloma. Int. J. Mol. Sci. 2020, 21, 7539. [CrossRef] 
51. Botta, C.; Cuce, M.; Caracciolo, D.; Fiorillo, L.; Tagliaferri, P.; Tassone, P. Immunomodulatory activity of microRNAs: Potential implications for multiple myeloma treatment. Curr. Cancer Drug Targets 2017, 17, 819-838. [CrossRef]

52. Witwer, K.W. Circulating microRNA biomarker studies: Pitfalls and potential solutions. Clin. Chem. 2015, 61, 56-63. [CrossRef]

53. Gasparri, M.L.; Casorelli, A.; Bardhi, E.; Besharat, A.R.; Savone, D.; Ruscito, I.; Farooqi, A.A.; Papadia, A.; Mueller, M.D.; Ferretti, E.; et al. Beyond circulating microRNA biomarkers: Urinary microRNAs in ovarian and breast cancer. Tumor Biol. $2017,39$. [CrossRef]

54. Wang, L.; Lv, J.; Guo, C.; Li, H.; Xiong, C. Recovery of cell-free mRNA and microRNA from human semen based on their physical nature. Biotechnol. Appl. Biochem. 2014, 61, 342-348. [CrossRef] [PubMed]

55. Chi, J.; Ballabio, E.; Chen, X.H.; Kusec, R.; Taylor, S.; Hay, D.; Tramonti, D.; Saunders, N.J.; Littlewood, T.; Pezzella, F.; et al. MicroRNA expression in multiple myeloma is associated with genetic subtype, isotype and survival. Biol. Direct $2011,6,23$. [CrossRef] [PubMed]

56. Marzi, M.J.; Ghini, F.; Cerruti, B.; de Pretis, S.; Bonetti, P.; Giacomelli, C.; Gorski, M.M.; Kress, T.; Pelizzola, M.; Muller, H.; et al. Degradation dynamics of microRNAs revealed by a novel pulse-chase approach. Genome Res. 2016, 26, 554-565. [CrossRef] [PubMed]

57. Fang, C.; Zhao, J.; Li, J.; Qian, J.; Liu, X.; Sun, Q.; Liu, W.; Tian, Y.; Ji, A.; Wu, H.; et al. Massively parallel sequencing of microRNA in bloodstains and evaluation of environmental influences on miRNA candidates using realtime polymerase chain reaction. Forensic Sci. Int. Genet. 2019, 38, 32-38. [CrossRef] [PubMed]

58. Roccaro, A.M.; Sacco, A.; Thompson, B.J.; Leleu, X.; Azab, A.K.; Azab, F.; Runnels, J.; Jia, X.; Ngo, H.T.; Melhem, M.R.; et al. MicroRNAs 15a and 16 regulate tumor proliferation in multiple myeloma. Blood 2009, 113, 6669-6680. [CrossRef]

59. Li, F.; Xu, Y.; Deng, S.; Li, Z.; Zou, D.; Yi, S.; Sui, W.; Hao, M.; Qiu, L. MicroRNA-15a/16-1 cluster located at chromosome 13q14 is down-regulated but displays different expression pattern and prognostic significance in multiple myeloma. Oncotarget 2015, 6, 38270-38282. [CrossRef] [PubMed]

60. Hao, M.; Zhang, L.; An, G.; Sui, W.; Yu, Z.; Zou, D.; Xu, Y.; Chang, H.; Qiu, L. Suppressing miRNA-15a/-16 expression by interleukin-6 enhances drug-resistance in myeloma cells. J. Hematol. Oncol. 2011, 4, 37. [CrossRef]

61. Gao, X.; Zhang, R.; Qu, X.; Zhao, M.; Zhang, S.; Wu, H.; Jianyong, L.; Chen, L. MiR-15a, miR-16-1 and miR-17-92 cluster expression are linked to poor prognosis in multiple myeloma. Leuk. Res. 2012, 36, 1505-1509. [CrossRef] [PubMed]

62. Novotny, G.W.; Sonne, S.B.; Nielsen, J.E.; Jonstrup, S.P.; Hansen, M.A.; Skakkebaek, N.E.; Rajpert-De Meyts, E.; Kjems, J.; Leffers, $\mathrm{H}$. Translational repression of E2F1 mRNA in carcinoma in situ and normal testis correlates with expression of the miR-17-92 cluster. Cell Death Differ. 2007, 14, 879-882. [CrossRef] [PubMed]

63. Wang, N.; Liang, X.; Yu, W.; Zhou, S.; Fang, M. Differential expression of microRNA-19b promotes proliferation of cancer stem cells by regulating the TSC1/mTOR signaling pathway in multiple myeloma. Cell. Physiol. Biochem. 2018, 50, 1804-1814. [CrossRef]

64. Xu, P.; Xia, T.; Ling, Y.; Chen, B. MiRNAs with prognostic significance in multiple myeloma: A systemic review and meta-analysis. Medicine 2019, 98, e16711. [CrossRef]

65. Razumilava, N.; Bronk, S.F.; Smoot, R.L.; Fingas, C.D.; Werneburg, N.W.; Roberts, L.R.; Mott, J.L. miR-25 targets TNF-related apoptosis inducing ligand (TRAIL) death receptor-4 and promotes apoptosis resistance in cholangiocarcinoma. Hepatology 2012, 55, 465-475. [CrossRef] [PubMed]

66. Qu, X.Y.; Zhang, S.S.; Wu, S.; Hong, M.; Li, J.Y.; Chen, L.J.; Xu, J.R. [Expression level of microRNA-92a and its clinical significance in multiple myeloma patients]. Zhonghua Xue Ye Xue Za Zhi 2013, 34, 332-336.

67. Jiang, Y.; Luan, Y.; Chang, H.; Chen, G. The diagnostic and prognostic value of plasma microRNA-125b-5p in patients with multiple myeloma. Oncol. Lett. 2018, 16, 4001-4007. [CrossRef] [PubMed]

68. Jiang, Y.; Ding, J.; Li, J.; Chen, G. Effects of microRNA125b on multiple myeloma cell growth in vitro and in vivo. Oncol. Rep. 2018, 40, 2864-2875.

69. Shen, X.; Kong, S.; Yang, Q.; Yin, Q.; Cong, H.; Wang, X.; Ju, S. PCAT-1 promotes cell growth by sponging miR-129 via MAP3K7/NF-kB pathway in multiple myeloma. J. Cell. Mol. Med. 2020, 24, 3492-3503. [CrossRef]

70. Xu, J.; Liao, X.; Wong, C. Downregulations of B-cell lymphoma 2 and myeloid cell leukemia sequence 1 by microRNA 153 induce apoptosis in a glioblastoma cell line DBTRG-05MG. Int. J. Cancer 2010, 126, 1029-1035. [CrossRef] [PubMed]

71. Pichiorri, F.; Suh, S.S.; Rocci, A.; De Luca, L.; Taccioli, C.; Santhanam, R.; Zhou, W.; Benson, D.M., Jr.; Hofmainster, C.; Alder, H.; et al. Downregulation of p53-inducible microRNAs 192, 194, and 215 impairs the p53/MDM2 autoregulatory loop in multiple myeloma development. Cancer Cell 2010, 18, 367-381. [CrossRef]

72. Gupta, N.; Kumar, R.; Seth, T.; Garg, B.; Sati, H.C.; Sharma, A. Clinical significance of circulatory microRNA-203 in serum as novel potential diagnostic marker for multiple myeloma. J. Cancer Res. Clin. Oncol. 2019, 145, 1601-1611. [CrossRef]

73. Liu, H.; Shen, Y.; Xu, Y.; Wang, L.; Zhang, C.; Jiang, Y.; Hong, L.; Huang, H.; Liu, H. lncRNA transcription factor 7 is related to deteriorating clinical features and poor prognosis in multiple myeloma, and its knockdown suppresses disease progression by regulating the miR-203-mediated Jagged1-Notch1 signaling pathway. Oncol. Lett. 2021, 21, 412. [CrossRef]

74. Wei, J.J.; Wu, X.; Peng, Y.; Shi, G.; Olca, B.; Yang, X.; Daniels, G.; Osman, I.; Ouyang, J.; Hernando, E.; et al. Regulation of HMGA1 expression by microRNA-296 affects prostate cancer growth and invasion. Clin. Cancer Res. 2011, 17, 1297-1305. [CrossRef] 
75. Huang, Q.; Gumireddy, K.; Schrier, M.; le Sage, C.; Nagel, R.; Nair, S.; Egan, D.A.; Li, A.; Huang, G.; Klein-Szanto, A.J.; et al. The microRNAs miR-373 and miR-520c promote tumour invasion and metastasis. Nat. Cell Biol. 2008, 10, 202-210. [CrossRef] [PubMed]

76. Yang, N.; Chen, J.; Zhang, H.; Wang, X.; Yao, H.; Peng, Y.; Zhang, W. LncRNA OIP5-AS1 loss-induced microRNA-410 accumulation regulates cell proliferation and apoptosis by targeting KLF10 via activating PTEN/PI3K/AKT pathway in multiple myeloma Cell Death Dis. 2017, 8, e2975. [CrossRef] [PubMed]

77. Jiang, M.; Zhou, L.Y.; Xu, N.; An, Q. Down-regulation of miR-500 and miR-628 suppress non-small cell lung cancer proliferation, migration and invasion by targeting ING1. Biomed. Pharmacother. 2018, 108, 1628-1639. [CrossRef] [PubMed]

78. Kubiczkova, L.; Kryukov, F.; Slaby, O.; Dementyeva, E.; Jarkovsky, J.; Nekvindova, J.; Radova, L.; Greslikova, H.; Kuglik, P.; Vetesnikova, E.; et al. Circulating serum microRNAs as novel diagnostic and prognostic biomarkers for multiple myeloma and monoclonal gammopathy of undetermined significance. Haematologica 2014, 99, 511-518. [CrossRef]

79. Sevcikova, S.; Kubiczkova, L.; Sedlarikova, L.; Slaby, O.; Hajek, R. Serum miR-29a as a marker of multiple myeloma. Leuk. Lymphoma 2013, 54, 189-191. [CrossRef] [PubMed]

80. Shen, X.; Ye, Y.; Qi, J.; Shi, W.; Wu, X.; Ni, H.; Cong, H.; Ju, S. Identification of a novel microRNA, miR-4449, as a potential blood based marker in multiple myeloma. Clin. Chem. Lab. Med. 2017, 55, 748-754. [CrossRef]

81. Zhu, B.; Chen, H.; Zhang, X.; Pan, Y.; Jing, R.; Shen, L.; Wang, X.; Ju, S.; Jin, C.; Cong, H. Serum miR-30d as a novel biomarker for multiple myeloma and its antitumor role in U266 cells through the targeting of the MTDH/PI3K/Akt signaling pathway. Int. J. Oncol. 2018, 53, 2131-2144. [CrossRef] [PubMed]

82. Corthals, S.L.; Sun, S.M.; Kuiper, R.; de Knegt, Y.; Broyl, A.; van der Holt, B.; Beverloo, H.B.; Peeters, J.K.; el Jarari, L.; Lokhorst, H.M.; et al. MicroRNA signatures characterize multiple myeloma patients. Leukemia 2011, 25, 1784-1789. [CrossRef] [PubMed]

83. Wu, P.; Agnelli, L.; Walker, B.A.; Todoerti, K.; Lionetti, M.; Johnson, D.C.; Kaiser, M.; Mirabella, F.; Wardell, C.; Gregory, W.M.; et al. Improved risk stratification in myeloma using a microRNA-based classifier. Br. J. Haematol. 2013, 162, 348-359. [CrossRef]

84. Hao, M.; Zang, M.; Wendlandt, E.; Xu, Y.; An, G.; Gong, D.; Li, F.; Qi, F.; Zhang, Y.; Yang, Y.; et al. Low serum miR-19a expression as a novel poor prognostic indicator in multiple myeloma. Int. J. Cancer 2015, 136, 1835-1844. [CrossRef]

85. Manier, S.; Liu, C.J.; Avet-Loiseau, H.; Park, J.; Shi, J.; Campigotto, F.; Salem, K.Z.; Huynh, D.; Glavey, S.V.; Rivotto, B.; et al. Prognostic role of circulating exosomal miRNAs in multiple myeloma. Blood 2017, 129, 2429-2436. [CrossRef] [PubMed]

86. Turner, K.J.; Vasu, V.; Griffin, D.K. Telomere biology and human phenotype. Cells 2019, 8, 73. [CrossRef]

87. Roake, C.M.; Artandi, S.E. Regulation of human telomerase in homeostasis and disease. Nat. Rev. Mol. Cell Biol. 2020, $21,384-397$. [CrossRef] [PubMed]

88. Wong, S.K.; Ima-Nirwana, S.; Chin, K.Y. Can telomere length predict bone health? A review of current evidence. Bosn. J. Basic Med. Sci. 2020, 20, 423-429. [CrossRef]

89. Barthel, F.P.; Wei, W.; Tang, M.; Martinez-Ledesma, E.; Hu, X.; Amin, S.B.; Akdemir, K.C.; Seth, S.; Song, X.; Wang, Q.; et al. Systematic analysis of telomere length and somatic alterations in 31 cancer types. Nat. Genet. 2017, 49, 349-357. [CrossRef] [PubMed]

90. Okamoto, K.; Seimiya, H. Revisiting telomere shortening in cancer. Cells 2019, 8, 107. [CrossRef]

91. Jafri, M.A.; Ansari, S.A.; Alqahtani, M.H.; Shay, J.W. Roles of telomeres and telomerase in cancer, and advances in telomerasetargeted therapies. Genome Med. 2016, 8, 69. [CrossRef]

92. Campa, D.; Martino, A.; Varkonyi, J.; Lesueur, F.; Jamroziak, K.; Landi, S.; Jurczyszyn, A.; Marques, H.; Andersen, V.; Jurado, M.; et al. Risk of multiple myeloma is associated with polymorphisms within telomerase genes and telomere length. Int. J. Cancer 2015, 136, E351-E358. [CrossRef] [PubMed]

93. Aref, S.; Al Saeed, A.; El Menshawy, N.; Abdalla, D.; El Ashery, M. Prognostic relevance of telomere length and telomerase reverse transcriptase variant (rs2242652) on the multiple myeloma patients. J. Clin. Lab. Anal. 2020, 34, e23133. [CrossRef]

94. Abdelrahman, A.H.; Eid, M.M.; Hassan, M.; Eid, O.M.; AbdelKader, R.M.A.; AlAzhary, N.M.; Shahin, R.Y.; Sallam, M.T. Telomerase reverse transcriptase gene amplification in hematological malignancies. Egypt J. Med. Hum. Genet. 2019, 20, 30. [CrossRef]

95. Rangel-Pozzo, A.; Yu, P.L.I.; La, L.S.; Asbaghi, Y.; Sisdelli, L.; Tammur, P.; Tamm, A.; Punab, M.; Klewes, L.; Louis, S.; et al. Telomere architecture correlates with aggressiveness in multiple myeloma. Cancers 2021, 13, 1969. [CrossRef] [PubMed]

96. Giaccherini, M.; Macauda, A.; Orciuolo, E.; Rymko, M.; Gruenpeter, K.; Dumontet, C.; Raźny, M.; Moreno, V.; Buda, G.; Beider, K.; et al. Genetically determined telomere length and multiple myeloma risk and outcome. Blood Cancer J. 2021, 11, 74. [CrossRef]

97. Hyatt, S.; Jones, R.E.; Heppel, N.H.; Grimstead, J.W.; Fegan, C.; Jackson, G.H.; Hills, R.; Allan, J.M.; Pratt, G.; Pepper, C.; et al. Telomere length is a critical determinant for survival in multiple myeloma. Br. J. Haematol. 2017, 178, 94-98. [CrossRef]

98. Hou, J.; Wei, R.; Qian, J.; Wang, R.; Fan, Z.; Gu, C.; Yang, Y. The impact of the bone marrow microenvironment on multiple myeloma (Review). Oncol. Rep. 2019, 42, 1272-1282. [CrossRef]

99. Glavey, S.V.; Naba, A.; Manier, S.; Clauser, K.; Tahri, S.; Park, J.; Reagan, M.R.; Moschetta, M.; Mishima, Y.; Gambella, M.; et al. Proteomic characterization of human multiple myeloma bone marrow extracellular matrix. Leukemia 2017, 31, 2426-2434. [CrossRef] [PubMed]

100. Peng, Y.; Wu, D.; Li, F.; Zhang, P.; Feng, Y.; He, A. Identification of key biomarkers associated with cell adhesion in multiple myeloma by integrated bioinformatics analysis. Cancer Cell Int. 2020, 20, 262. [CrossRef] [PubMed] 
101. Mekhloufi, A.; Kosta, A.; Stabile, H.; Molfetta, R.; Zingoni, A.; Soriani, A.; Cippitelli, M.; Paolini, R.; Gismondi, A.; Ricciardi, M.R.; et al. Bone marrow stromal cell-derived IL-8 upregulates PVR expression on multiple myeloma cells via NF-kB transcription factor. Cancers 2020, 12, 440. [CrossRef]

102. Frassanito, M.A.; Desantis, V.; Di Marzo, L.; Craparotta, I.; Beltrame, L.; Marchini, S.; Annese, T.; Visino, F.; Arciuli, M.; Saltarella, I.; et al. Bone marrow fibroblasts overexpress miR-27b and miR-214 in step with multiple myeloma progression, dependent on tumour cell-derived exosomes. J. Pathol. 2019, 247, 241-253. [CrossRef]

103. Slany, A.; Haudek-Prinz, V.; Meshcheryakova, A.; Bileck, A.; Lamm, W.; Zielinski, C.; Gerner, C.; Drach, J. Extracellular matrix remodeling by bone marrow fibroblast-like cells correlates with disease progression in multiple myeloma. J. Proteome Res. 2014, 13, 844-854. [CrossRef] [PubMed]

104. Vij, R.; Mazumder, A.; Klinger, M.; O’Dea, D.; Paasch, J.; Martin, T.; Weng, L.; Park, J.; Fiala, M.; Faham, M.; et al. Deep sequencing reveals myeloma cells in peripheral blood in majority of multiple myeloma patients. Clin. Lymphoma Myeloma Leuk. 2014, 14, 131-139.e131. [CrossRef] [PubMed]

105. Mishima, Y.; Paiva, B.; Shi, J.; Park, J.; Manier, S.; Takagi, S.; Massoud, M.; Perilla-Glen, A.; Aljawai, Y.; Huynh, D.; et al. The mutational landscape of circulating tumor cells in multiple myeloma. Cell Rep. 2017, 19, 218-224. [CrossRef]

106. Bianchi, G.; Kyle, R.A.; Larson, D.R.; Witzig, T.E.; Kumar, S.; Dispenzieri, A.; Morice, W.G.; Rajkumar, S.V. High levels of peripheral blood circulating plasma cells as a specific risk factor for progression of smoldering multiple myeloma. Leukemia 2013, 27, 680-685. [CrossRef] [PubMed]

107. Gonsalves, W.I.; Rajkumar, S.V.; Dispenzieri, A.; Dingli, D.; Timm, M.M.; Morice, W.G.; Lacy, M.Q.; Buadi, F.K.; Go, R.S.; Leung, N.; et al. Quantification of circulating clonal plasma cells via multiparametric flow cytometry identifies patients with smoldering multiple myeloma at high risk of progression. Leukemia 2017, 31, 130-135. [CrossRef]

108. Gonsalves, W.I.; Morice, W.G.; Rajkumar, V.; Gupta, V.; Timm, M.M.; Dispenzieri, A.; Buadi, F.K.; Lacy, M.Q.; Singh, P.P.; Kapoor, P.; et al. Quantification of clonal circulating plasma cells in relapsed multiple myeloma. Br. J. Haematol. 2014, 167, 500-505. [CrossRef]

109. Paiva, B.; Puig, N.; Cedena, M.T.; de Jong, B.G.; Ruiz, Y.; Rapado, I.; Martinez-Lopez, J.; Cordon, L.; Alignani, D.; Delgado, J.A.; et al. Differentiation stage of myeloma plasma cells: Biological and clinical significance. Leukemia 2017, 31, 382-392. [CrossRef]

110. Peceliunas, V.; Janiulioniene, A.; Matuzeviciene, R.; Zvirblis, T.; Griskevicius, L. Circulating plasma cells predict the outcome of relapsed or refractory multiple myeloma. Leuk. Lymphoma 2012, 53, 641-647. [CrossRef]

111. Chakraborty, R.; Muchtar, E.; Kumar, S.K.; Jevremovic, D.; Buadi, F.K.; Dingli, D.; Dispenzieri, A.; Hayman, S.R.; Hogan, W.J.; Kapoor, P.; et al. Risk stratification in myeloma by detection of circulating plasma cells prior to autologous stem cell transplantation in the novel agent era. Blood Cancer J. 2016, 6, e512. [CrossRef] [PubMed]

112. Sanoja-Flores, L.; Flores-Montero, J.; Garces, J.J.; Paiva, B.; Puig, N.; Garcia-Mateo, A.; Garcia-Sanchez, O.; Corral-Mateos, A.; Burgos, L.; Blanco, E.; et al. Next generation flow for minimally-invasive blood characterization of MGUS and multiple myeloma at diagnosis based on circulating tumor plasma cells (CTPC). Blood Cancer J. 2018, 8, 117. [CrossRef]

113. Kis, O.; Kaedbey, R.; Chow, S.; Danesh, A.; Dowar, M.; Li, T.; Li, Z.; Liu, J.; Mansour, M.; Masih-Khan, E.; et al. Circulating tumour DNA sequence analysis as an alternative to multiple myeloma bone marrow aspirates. Nat. Commun. 2017, 8, 15086. [CrossRef]

114. Mithraprabhu, S.; Khong, T.; Ramachandran, M.; Chow, A.; Klarica, D.; Mai, L.; Walsh, S.; Broemeling, D.; Marziali, A.; Wiggin, M.; et al. Circulating tumour DNA analysis demonstrates spatial mutational heterogeneity that coincides with disease relapse in myeloma. Leukemia 2017, 31, 1695-1705. [CrossRef]

115. Mithraprabhu, S.; Sirdesai, S.; Chen, M.; Khong, T.; Spencer, A. Circulating tumour DNA analysis for tumour genome characterisation and monitoring disease burden in extramedullary multiple myeloma. Int. J. Mol. Sci. 2018, 19, 1858. [CrossRef]

116. Mithraprabhu, S.; Morley, R.; Khong, T.; Kalff, A.; Bergin, K.; Hocking, J.; Savvidou, I.; Bowen, K.M.; Ramachandran, M.; Choi, K.; et al. Monitoring tumour burden and therapeutic response through analysis of circulating tumour DNA and extracellular RNA in multiple myeloma patients. Leukemia 2019, 33, 2022-2033. [CrossRef] [PubMed]

117. Manier, S.; Park, J.; Capelletti, M.; Bustoros, M.; Freeman, S.S.; Ha, G.; Rhoades, J.; Liu, C.J.; Huynh, D.; Reed, S.C.; et al. Whole-exome sequencing of cell-free DNA and circulating tumor cells in multiple myeloma. Nat. Commun. 2018, 9, 1691. [CrossRef] [PubMed]

118. Campo, C.; da Silva Filho, M.I.; Weinhold, N.; Mahmoudpour, S.H.; Goldschmidt, H.; Hemminki, K.; Merz, M.; Forsti, A. Bortezomib-induced peripheral neuropathy: A genome-wide association study on multiple myeloma patients. Hematol. Oncol. 2018, 36, 232-237. [CrossRef]

119. Zmorzynski, S.; Popek-Marciniec, S.; Szudy-Szczyrek, A.; Wojcierowska-Litwin, M.; Korszen-Pilecka, I.; Chocholska, S.; Styk, W.; Hus, M.; Filip, A.A. The association of GSTT1, GSTM1, and TNF-a polymorphisms with the risk and outcome in multiple myeloma. Front. Oncol. 2019, 9, 1056. [CrossRef] [PubMed]

120. Sawyer, J.R.; Tian, E.; Shaughnessy, J.D., Jr.; Epstein, J.; Swanson, C.M.; Stangeby, C.; Hale, C.L.; Parr, L.; Lynn, M.; Sammartino, G.; et al. Hyperhaploidy is a novel high-risk cytogenetic subgroup in multiple myeloma. Leukemia 2017, 31, 637-644. [CrossRef]

121. Thakurta, A.; Ortiz, M.; Blecua, P.; Towfic, F.; Corre, J.; Serbina, N.V.; Flynt, E.; Yu, Z.; Yang, Z.; Palumbo, A.; et al. High subclonal fraction of 17p deletion is associated with poor prognosis in multiple myeloma. Blood 2019, 133, 1217-1221. [CrossRef] [PubMed]

122. Serin, I.; Pehlivan, S.; Gundes, I.; Fidan Oyaci, Y.; Pehlivan, M. A new parameter in multiple myeloma: CYP3A4*1B single nucleotide polymorphism. Ann. Hematol. 2021, 100, 421-427. [CrossRef] [PubMed] 
123. Niebudek, K.; Balcerczak, E.; Mirowski, M.; Pietrzak, J.; Zawadzka, I.; Zebrowska-Nawrocka, M. The contribution of ABCG2 G34A and C421A polymorphisms to multiple myeloma susceptibility. OncoTargets Ther. 2019, 12, 1655-1660. [CrossRef] [PubMed]

124. Ishibashi, M.; Sunakawa-Kii, M.; Kaito, Y.; Kinoshita, R.; Asayama, T.; Kuribayashi, Y.; Inokuchi, K.; Morita, R.; Tamura, H. The SLAMF3 rs509749 polymorphism correlates with malignant potential in multiple myeloma. Exp. Hematol. 2020, 90, 72-79. [CrossRef]

125. Kasamatsu, T.; Awata, M.; Ishihara, R.; Murakami, Y.; Gotoh, N.; Matsumoto, M.; Sawamura, M.; Yokohama, A.; Handa, H.; Tsukamoto, N.; et al. PDCD1 and PDCD1LG1 polymorphisms affect the susceptibility to multiple myeloma. Clin. Exp. Med. 2020, 20, 51-62. [CrossRef]

126. Poi, M.J.; Li, J.; Johnson, J.A.; Cho, Y.K.; Sborov, D.W.; Phelps, M.A.; Hofmeister, C.C. A single nucleotide polymorphism in SLC7A5 was associated with clinical response in multiple myeloma patients. Anticancer Res. 2019, 39, 67-72. [CrossRef]

127. Barrio, S.; Munawar, U.; Zhu, Y.X.; Giesen, N.; Shi, C.X.; Via, M.D.; Sanchez, R.; Bruins, L.; Demler, T.; Muller, N.; et al. IKZF1/3 and CRL4 ${ }^{\text {CRBN }}$ E3 ubiquitin ligase mutations and resistance to immunomodulatory drugs in multiple myeloma. Haematologica 2020, 105, e237-e241. [CrossRef]

128. Zhang, H.T.; Tian, E.B.; Chen, Y.L.; Deng, H.T.; Wang, Q.T. Proteomic analysis for finding serum pathogenic factors and potential biomarkers in multiple myeloma. Chin. Med. J. 2015, 128, 1108-1113. [CrossRef]

129. Ma, T.Z.; Piao, Z.; Jin, S.Y.; Kwak, Y.G. Differential expression of serum proteins in multiple myeloma. Exp. Ther. Med. 2019, 17, 649-656. [CrossRef]

130. Chanukuppa, V.; Taware, R.; Taunk, K.; Chatterjee, T.; Sharma, S.; Somasundaram, V.; Rashid, F.; Malakar, D.; Santra, M.K.; Rapole, S. Proteomic alterations in multiple myeloma: A comprehensive study using bone marrow interstitial fluid and serum samples. Front. Oncol. 2020, 10, 566804. [CrossRef]

131. Dytfeld, D.; Luczak, M.; Wrobel, T.; Usnarska-Zubkiewicz, L.; Brzezniakiewicz, K.; Jamroziak, K.; Giannopoulos, K.; PrzybylowiczChalecka, A.; Ratajczak, B.; Czerwinska-Rybak, J.; et al. Comparative proteomic profiling of refractory/relapsed multiple myeloma reveals biomarkers involved in resistance to bortezomib-based therapy. Oncotarget 2016, 7, 56726-56736. [CrossRef]

132. Luczak, M.; Kubicki, T.; Rzetelska, Z.; Szczepaniak, T.; Przybylowicz-Chalecka, A.; Ratajczak, B.; Czerwinska-Rybak, J.; Nowicki, A.; Joks, M.; Jakubowiak, A.; et al. Comparative proteomic profiling of sera from patients with refractory multiple myeloma reveals potential biomarkers predicting response to bortezomib-based therapy. Pol. Arch. Intern. Med. 2017, 127, 392-400.

133. Rajpal, R.; Dowling, P.; Meiller, J.; Clarke, C.; Murphy, W.G.; O'Connor, R.; Kell, M.; Mitsiades, C.; Richardson, P.; Anderson, K.C.; et al. A novel panel of protein biomarkers for predicting response to thalidomide-based therapy in newly diagnosed multiple myeloma patients. Proteomics 2011, 11, 1391-1402. [CrossRef]

134. Lonial, S.; Dimopoulos, M.; Palumbo, A.; White, D.; Grosicki, S.; Spicka, I.; Walter-Croneck, A.; Moreau, P.; Mateos, M.V.; Magen, H.; et al. Elotuzumab Therapy for Relapsed or Refractory Multiple Myeloma. N. Engl. J. Med. 2015, 373, 621-631. [CrossRef]

135. Lokhorst, H.M.; Plesner, T.; Laubach, J.P.; Nahi, H.; Gimsing, P.; Hansson, M.; Minnema, M.C.; Lassen, U.; Krejcik, J.; Palumbo, A.; et al. Targeting CD38 with daratumumab monotherapy in multiple myeloma. N. Engl. J. Med. 2015, 373, 1207-1219. [CrossRef]

136. Nijhof, I.S.; Casneuf, T.; van Velzen, J.; van Kessel, B.; Axel, A.E.; Syed, K.; Groen, R.W.; van Duin, M.; Sonneveld, P.; Minnema, M.C.; et al. CD38 expression and complement inhibitors affect response and resistance to daratumumab therapy in myeloma. Blood 2016, 128, 959-970. [CrossRef] [PubMed]

137. Romano, A.; Parrinello, N.L.; Simeon, V.; Puglisi, F.; La Cava, P.; Bellofiore, C.; Giallongo, C.; Camiolo, G.; D’Auria, F.; Grieco, V.; et al. High-density neutrophils in MGUS and multiple myeloma are dysfunctional and immune-suppressive due to increased STAT3 downstream signaling. Sci. Rep. 2020, 10, 1983. [CrossRef]

138. Spath, F.; Wibom, C.; Krop, E.J.M.; Santamaria, A.I.; Johansson, A.S.; Bergdahl, I.A.; Hultdin, J.; Vermeulen, R.; Melin, B. Immune marker changes and risk of multiple myeloma: A nested case-control study using repeated pre-diagnostic blood samples. Haematologica 2019, 104, 2456-2464. [CrossRef]

139. Vermeulen, R.; Saberi Hosnijeh, F.; Bodinier, B.; Portengen, L.; Liquet, B.; Garrido-Manriquez, J.; Lokhorst, H.; Bergdahl, I.A.; Kyrtopoulos, S.A.; Johansson, A.S.; et al. Pre-diagnostic blood immune markers, incidence and progression of B-cell lymphoma and multiple myeloma: Univariate and functionally informed multivariate analyses. Int. J. Cancer 2018, 143, 1335-1347. [CrossRef]

140. Ye, R.; Kundrapu, S.; Gerson, S.L.; Driscoll, J.J.; Beck, R.; Ali, N.; Landgren, O.; VanHeeckeren, W.; Luo, G.; Kroger, N.; et al. Immune signatures associated with clonal isotype switch after autologous stem cell transplantation for multiple myeloma. Clin. Lymphoma Myeloma Leuk. 2019, 19, e213-e220. [CrossRef] [PubMed]

141. Dosani, T.; Covut, F.; Beck, R.; Driscoll, J.J.; de Lima, M.; Malek, E. Significance of the absolute lymphocyte/monocyte ratio as a prognostic immune biomarker in newly diagnosed multiple myeloma. Blood Cancer J. 2017, 7, e579. [CrossRef]

142. Wei, M.; Guo, H.; Liu, S.; Xu, F.; Zhang, Y.; Shi, J.; Xu, Z.; Chen, Y. Effect of immune score at initial diagnosis in predicting prognosis in patients with multiple myeloma treated with bortezomib. J. Clin. Med. Pract. 2021, 25, 46-51.

143. Tian, Y.; Zhang, Y.; Zhu, W.Q.; Chen, X.L.; Zhou, H.B.; Chen, W.M. Peripheral blood lymphocyte-to-monocyte ratio as a useful prognostic factor in newly diagnosed multiple myeloma. BioMed Res. Int. 2018, 2018, 9434637. [CrossRef] [PubMed]

144. Sweiss, K.; Lee, J.; Mahmud, N.; Calip, G.S.; Park, Y.; Mahmud, D.; Rondelli, D.; Patel, P.R. Combined immune score of lymphocyte to monocyte ratio and immunoglobulin levels predicts treatment-free survival of multiple myeloma patients after autologous stem cell transplant. Bone Marrow Transplant. 2020, 55, 199-206. [CrossRef] 
145. Pang, Y.; Shao, H.; Yang, Z.; Fan, L.; Liu, W.; Shi, J.; Wang, Y.; Han, Y.; Yang, L. The (neutrophils + monocyte)/lymphocyte ratio is an independent prognostic factor for progression-free survival in newly diagnosed multiple myeloma patients treated with BCD regimen. Front. Oncol. 2020, 10, 1617. [CrossRef] [PubMed]

146. Yang, Y.; Liu, Z.; Wang, H. Peripheral absolute lymphocyte count: An economical and clinical available immune-related prognostic marker for newly diagnosed multiple myeloma. Med. Sci. Monit. 2020, 26, e923716. [CrossRef]

147. Awwad, M.H.S.; Kriegsmann, K.; Plaumann, J.; Benn, M.; Hillengass, J.; Raab, M.S.; Bertsch, U.; Munder, M.; Weisel, K.; Salwender, H.J.; et al. The prognostic and predictive value of IKZF1 and IKZF3 expression in T-cells in patients with multiple myeloma. Oncoimmunology 2018, 7, e1486356. [CrossRef] [PubMed]

148. Landgren, O.; Hofmann, J.N.; McShane, C.M.; Santo, L.; Hultcrantz, M.; Korde, N.; Mailankody, S.; Kazandjian, D.; Murata, K.; Thoren, K.; et al. Association of immune marker changes with progression of monoclonal gammopathy of undetermined significance to multiple myeloma. JAMA Oncol. 2019, 5, 1293-1301. [CrossRef] [PubMed]

149. Ding, Z.; Li, Q.; Zhang, R.; Xie, L.; Shu, Y.; Gao, S.; Wang, P.; Su, X.; Qin, Y.; Wang, Y.; et al. Personalized neoantigen pulsed dendritic cell vaccine for advanced lung cancer. Signal Transduct. Target. Ther. 2021, 6, 26. [CrossRef]

150. Han, X.J.; Ma, X.L.; Yang, L.; Wei, Y.Q.; Peng, Y.; Wei, X.W. Progress in neoantigen targeted cancer immunotherapies. Front. Cell Dev. Biol. 2020, 8, 728. [CrossRef]

151. Jou, J.; Harrington, K.J.; Zocca, M.B.; Ehrnrooth, E.; Cohen, E.E.W. The changing landscape of therapeutic cancer vaccines-Novel platforms and neoantigen identification. Clin. Cancer Res. 2021, 27, 689-703. [CrossRef]

152. Miller, A.; Asmann, Y.; Cattaneo, L.; Braggio, E.; Keats, J.; Auclair, D.; Lonial, S.; Network, M.C.; Russell, S.J.; Stewart, A.K. High somatic mutation and neoantigen burden are correlated with decreased progression-free survival in multiple myeloma. Blood Cancer J. 2017, 7, e612. [CrossRef]

153. Perumal, D.; Imai, N.; Lagana, A.; Finnigan, J.; Melnekoff, D.; Leshchenko, V.V.; Solovyov, A.; Madduri, D.; Chari, A.; Cho, H.J.; et al. Mutation-derived neoantigen-specific T-cell responses in multiple myeloma. Clin. Cancer Res. 2020, 26, 450-464. [CrossRef]

154. Doan, M.; Vorobjev, I.; Rees, P.; Filby, A.; Wolkenhauer, O.; Goldfeld, A.E.; Lieberman, J.; Barteneva, N.; Carpenter, A.E.; Hennig, H. Diagnostic potential of imaging flow cytometry. Trends Biotechnol. 2018, 36, 649-652. [CrossRef]

155. Paiva, B.; Vidriales, M.B.; Cervero, J.; Mateo, G.; Perez, J.J.; Montalban, M.A.; Sureda, A.; Montejano, L.; Gutierrez, N.C.; Garcia de Coca, A.; et al. Multiparameter flow cytometric remission is the most relevant prognostic factor for multiple myeloma patients who undergo autologous stem cell transplantation. Blood 2008, 112, 4017-4023. [CrossRef]

156. Soh, K.T.; Wallace, P.K. Monitoring of measurable residual disease in multiple myeloma by multiparametric flow cytometry. Curr Protoc. Cytom. 2019, 90, e63. [CrossRef]

157. Li, H.; Li, F.; Zhou, X.; Mei, J.; Song, P.; An, Z.; Zhao, Q.; Guo, X.; Wang, X.; Zhai, Y. Achieving minimal residual disease-negative by multiparameter flow cytometry may ameliorate a poor prognosis in MM patients with high-risk cytogenetics: A retrospective single-center analysis. Ann. Hematol. 2019, 98, 1185-1195. [CrossRef] [PubMed]

158. Guo, J.; Su, J.; He, Q.; Li, X.; Zhao, Y.; Gu, S.; Fei, C.; Chang, C. The prognostic impact of multiparameter flow cytometry immunophenotyping and cytogenetic aberrancies in patients with multiple myeloma. Hematology 2016, 21, 152-161. [CrossRef] [PubMed]

159. Bolli, N.; Genuardi, E.; Ziccheddu, B.; Martello, M.; Oliva, S.; Terragna, C. Next-generation sequencing for clinical management of multiple myeloma: Ready for prime time? Front. Oncol. 2020, 10, 189. [CrossRef] [PubMed]

160. Jimenez, C.; Jara-Acevedo, M.; Corchete, L.A.; Castillo, D.; Ordonez, G.R.; Sarasquete, M.E.; Puig, N.; Martinez-Lopez, J.; Prieto-Conde, M.I.; Garcia-Alvarez, M.; et al. A next-generation sequencing strategy for evaluating the most common genetic abnormalities in multiple myeloma. J. Mol. Diagn. 2017, 19, 99-106. [CrossRef]

161. D’Agostino, M.; Zaccaria, G.M.; Ziccheddu, B.; Rustad, E.H.; Genuardi, E.; Capra, A.; Oliva, S.; Auclair, D.; Yesil, J.; Colucci, P.; et al. Early Relapse risk in patients with newly diagnosed multiple myeloma characterized by next-generation sequencing. Clin. Cancer Res. 2020, 26, 4832-4841. [CrossRef]

162. Zhang, L.; Beasley, S.; Prigozhina, N.L.; Higgins, R.; Ikeda, S.; Lee, F.Y.; Marrinucci, D.; Jia, S. Detection and characterization of circulating tumour cells in multiple myeloma. J. Circ. Biomark. 2016, 5, 10. [CrossRef]

163. Mithraprabhu, S.; Spencer, A. Circulating tumour DNA analysis in multiple myeloma. Oncotarget 2017, 8, 90610-90611. [CrossRef] [PubMed]

164. Zhang, L.; Pan, L.; Xiang, B.; Zhu, H.; Wu, Y.; Chen, M.; Guan, P.; Zou, X.; Valencia, C.A.; Dong, B.; et al. Potential role of exosome-associated microRNA panels and in vivo environment to predict drug resistance for patients with multiple myeloma. Oncotarget 2016, 7, 30876-30891. [CrossRef]

165. Rasmussen, T.; Poulsen, T.S.; Honore, L.; Johnsen, H.E. Quantitation of minimal residual disease in multiple myeloma using an allele-specific real-time PCR assay. Exp. Hematol. 2000, 28, 1039-1045. [CrossRef]

166. Takamatsu, H.; Murata, R.; Zheng, J.; Moorhead, M.; Terasaki, Y.; Yoshida, T.; Faham, M.; Nakao, S. A comparison between next-generation sequencing and ASO-qPCR for minimal residual disease detection in multiple myeloma. J. Clin. Oncol. 2013, 31, 8601. [CrossRef]

167. Bakkus, M.H.; Bouko, Y.; Samson, D.; Apperley, J.F.; Thielemans, K.; Van Camp, B.; Benner, A.; Goldschmidt, H.; Moos, M.; Cremer, F.W. Post-transplantation tumour load in bone marrow, as assessed by quantitative ASO-PCR, is a prognostic parameter in multiple myeloma. Br. J. Haematol. 2004, 126, 665-674. [CrossRef] 
168. Rawstron, A.C.; Child, J.A.; de Tute, R.M.; Davies, F.E.; Gregory, W.M.; Bell, S.E.; Szubert, A.J.; Navarro-Coy, N.; Drayson, M.T.; Feyler, S.; et al. Minimal residual disease assessed by multiparameter flow cytometry in multiple myeloma: Impact on outcome in the Medical Research Council Myeloma IX Study. J. Clin. Oncol. 2013, 31, 2540-2547. [CrossRef] [PubMed]

169. Paiva, B.; Vidriales, M.B.; Montalban, M.A.; Perez, J.J.; Gutierrez, N.C.; Rosinol, L.; Martinez-Lopez, J.; Mateos, M.V.; Cordon, L.; Oriol, A.; et al. Multiparameter flow cytometry evaluation of plasma cell DNA content and proliferation in 595 transplant-eligible patients with myeloma included in the Spanish GEM2000 and GEM2005. Am. J. Pathol. 2012, 181, 1870-1878. [CrossRef]

170. Terpos, E.; Kostopoulos, I.V.; Kastritis, E.; Ntanasis-Stathopoulos, I.; Migkou, M.; Rousakis, P.; Argyriou, A.T.; Kanellias, N.; Fotiou, D.; Eleutherakis-Papaiakovou, E.; et al. Impact of minimal residual disease detection by next-generation flow cytometry in multiple myeloma patients with sustained complete remission after frontline therapy. Hemasphere 2019, 3, e300. [CrossRef]

171. Paiva, B.; van Dongen, J.J.; Orfao, A. New criteria for response assessment: Role of minimal residual disease in multiple myeloma. Blood 2015, 125, 3059-3068. [CrossRef] [PubMed]

172. Kumar, S.; Paiva, B.; Anderson, K.C.; Durie, B.; Landgren, O.; Moreau, P.; Munshi, N.; Lonial, S.; Bladé, J.; Mateos, M.-V.; et al. International Myeloma Working Group consensus criteria for response and minimal residual disease assessment in multiple myeloma. Lancet Oncol. 2016, 17, e328-e346. [CrossRef]

173. Maclachlan, K.H.; Came, N.; Diamond, B.; Roshal, M.; Ho, C.; Thoren, K.; Mayerhoefer, M.E.; Landgren, O.; Harrison, S. Minimal residual disease in multiple myeloma: Defining the role of next generation sequencing and flow cytometry in routine diagnostic use. Pathology 2021, 53, 385-399. [CrossRef]

174. Takamatsu, H.; Yoroidaka, T.; Fujisawa, M.; Kobori, K.; Hanawa, M.; Yamashita, T.; Murata, R.; Ueda, M.; Nakao, S.; Matsue, K. Comparison of minimal residual disease detection in multiple myeloma by SRL 8-color single-tube and EuroFlow 8-color 2-tube multiparameter flow cytometry. Int. J. Hematol. 2019, 109, 377-381. [CrossRef] [PubMed]

175. Martinez-Lopez, J.; Lahuerta, J.J.; Pepin, F.; Gonzalez, M.; Barrio, S.; Ayala, R.; Puig, N.; Montalban, M.A.; Paiva, B.; Weng, L.; et al. Prognostic value of deep sequencing method for minimal residual disease detection in multiple myeloma. Blood 2014, 123, 3073-3079. [CrossRef]

176. Yao, Q.; Bai, Y.; Orfao, A.; Chim, C.S. Standardized minimal residual disease detection by next-generation sequencing in multiple myeloma. Front. Oncol. 2019, 9, 449. [CrossRef] [PubMed]

177. Yao, Q.; Bai, Y.; Orfao, A.; Kumar, S.; Chim, C.S. Upgraded standardized minimal residual disease detection by next-generation sequencing in multiple myeloma. J. Mol. Diagn. 2020, 22, 679-684. [CrossRef]

178. Avet-Loiseau, H.; Corre, J.; Lauwers-Cances, V.; Chrétien, M.; Robillard, N.; Leleu, X.; Hulin, C.; Gentil, C.; Arnulf, B.; Belhadj, K.; et al. Evaluation of minimal residual disease (MRD) by next generation sequencing (NGS) is highly predictive of progression free survival in the IFM/DFCI 2009 trial. Blood 2015, 126, 191. [CrossRef]

179. Oran, B.; Malek, K.; Sanchorawala, V.; Wright, D.G.; Quillen, K.; Finn, K.T.; La Valley, M.; Skinner, M.; Seldin, D.C. Predictive factors for hematopoietic engraftment after autologous peripheral blood stem cell transplantation for AL amyloidosis. Bone Marrow Transplant. 2005, 35, 567-575. [CrossRef]

180. Rajeev Krishnan, S.; De Rubis, G.; Suen, H.; Joshua, D.; Lam Kwan, Y.; Bebawy, M. A liquid biopsy to detect multidrug resistance and disease burden in multiple myeloma. Blood Cancer J. 2020, 10, 37. [CrossRef]

181. Puig, N.; Sarasquete, M.E.; Balanzategui, A.; Martinez, J.; Paiva, B.; Garcia, H.; Fumero, S.; Jimenez, C.; Alcoceba, M.; Chillon, M.C.; et al. Critical evaluation of ASO RQ-PCR for minimal residual disease evaluation in multiple myeloma. A comparative analysis with flow cytometry. Leukemia 2014, 28, 391-397. [CrossRef] 